\title{
Hódosy Annamária
}

\section{Mi vagyunk a vírus?}

\section{A fertőzés mint ökopolitikai metafora a járványfilmekben, a szörnyfilmekben és a kulturális képzeletben}

\begin{abstract}
Absztrakt
2020 márciusában a járványügyi veszélyhelyzet kihirdetése után a közösségi médiában igen népszerü lett egy mémsorozat, mely szerint „A természet gyógyul. Mi vagyunk a vírus. A koronavírus pedig a gyógymód." Mint a dolgozat bemutatja, ez a szlogen 25 éves, az elképzelés pedig még régebbre vezethetô vissza, és számtalan járványfilm üzenetét meghatározza, ahol a vírus és az egyes embercsoportok és viselkedésmódok metaforikus asszociációja annak megfelelóen módosult, hogy éppen mi a domináns elképzelés a bolygó ökológiai problémájának eredetét és a megoldásához szükséges tennivalókat illetôen. Míg ezek a vírushoz (és egyéb mikroszkopikus kórokozókhoz) kapcsolódó metaforikus képzetek a járványfilmekben általában a narrációhoz kapcsolódnak, és a vírus csak a kommentárban válik a bolygó „immunrendszerének” képviselójévé, a szörnyfilmekben a viralitás a karakterek ábrázolásának integráns részét képezi, ami elsôsorban arra látszik alkalmasnak lenni, hogy legitimálja a vírus - és ennélfogva a Természet - ellen folytatott háborút. Az újabb zombifilmek viszont túllépnek ezen, és gyakran a járványhelyzet megoldásának olyan szimulációit kínálják, amelyek a klímaválság kezelési lehetôségeként is értelmezhetôk.
\end{abstract}

\section{Szerzó}

Hódosy Annamária az SZTE Vizuális Kultúra és Irodalomelmélet Tanszék oktatója, magyarangol-összehasonlító irodalomtudomány szakon végzett a Szegedi Tudományegyetemen. Tagja volt a posztstrukturalista irodalomtudományt Magyarországon népszerúsító deKON-csoportnak (1992-2004). Jelenleg elsôsorban ökokritikával és ökofeminizmussal, illetve a populáris film trendjeinek társadalmi okaival foglalkozik. Biomozi. Ökokritika és populáris film címú könyve 2018ban jelent meg. Számos tanulmánya olvasható a deKON-könyvekben az Ictus/JATE Irodalomelméleti Csoport gondozásában, a Literatura, Tiszatáj folyóiratokban és az TNTeF e- 
folyóiratban.

E-mail: hodosy.annamaria@gmail.com

https://doi.org/10.31176/apertura.2020.16.1.8 


\section{Mi vagyunk a vírus?}

\section{A fertôzés mint ökopolitikai metafora a járványfilmekben, a szörnyfilmekben és a kulturális képzeletben}

\section{A „beteg” bolygó}

2020 márciusában a járványügyi veszélyhelyzet kihirdetése után a közösségi médiában olyan bejegyzések bukkantak fel egyre-másra, amelyek boldogan tudatosítottak a természet megújulásáról és a vadon élô állatok újramegjelenésérôl a városokban. Némelyek ebből gyorsan levonták azt a hangzatos, s a vírushelyzetet poétikai szempontból ügyesen a klímahelyzettel összekapcsoló következtetést, hogy „A természet gyógyul. Mi vagyunk a vírus. A koronavírus pedig a gyógymód." A természet feléledésérôl szóló hírek egy részét azután cáfolták, azok ellen pedig, akik a koronavírus pozitív ökológiai hatásáról írtak bejegyzést, kisebbfajta boszorkányüldözés indult, gyakran azzal az indokkal, hogy olyasvalamit üdvözölni, ami amúgy százezrek halálát idézi elő, az „ökofasizmus” jele (vö. Lambermont 2020). Számos ilyen bejegyzést ezután töröltek is, a helyükbe pedig a mémek egy olyan formája lépett és vált egycsapásra népszerūvé, amely az idézett „sötétzöld” szlogent a városban felbukkanó dinoszauruszok vagy dodók, a karanténba vonult emberek helyét elfoglaló macskák vagy éppen természeti környezetbe helyezett plüssállatok photoshoppal megszerkesztett vicces képeivel illusztrálva parodizálták. 


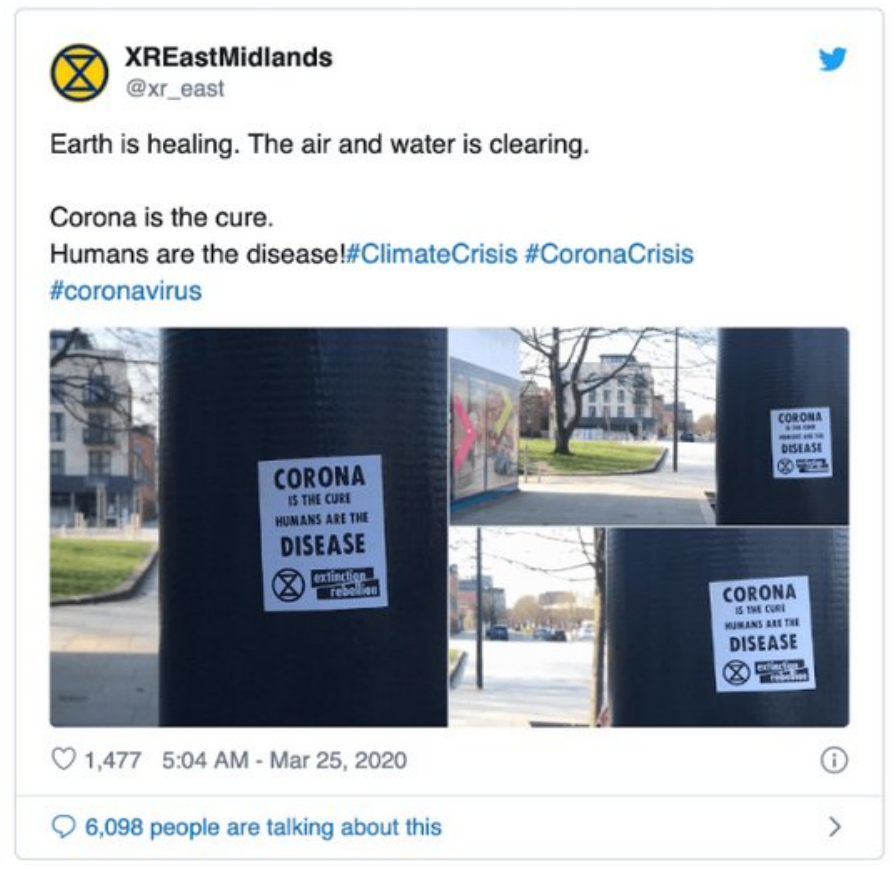

Az első, még komoly „mi vagyunk a vírus” mém egyike.
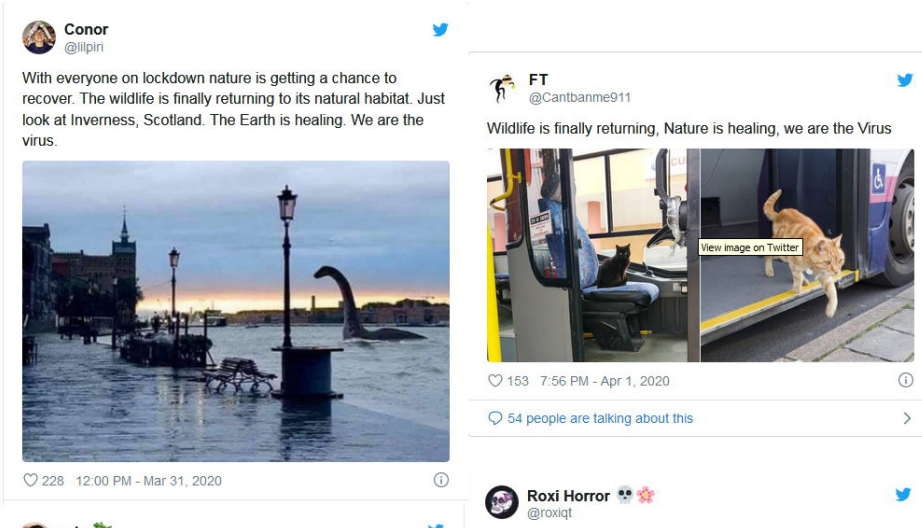

19 ruby के

$\checkmark$

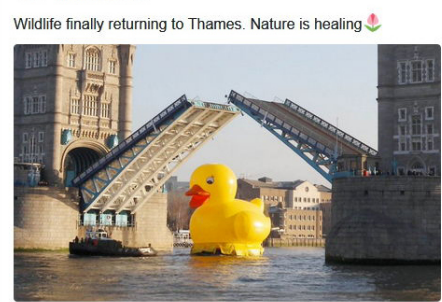

With everyone on lockdown, the furbies are returning to the forests \& the earth is healing. Nature is amazing

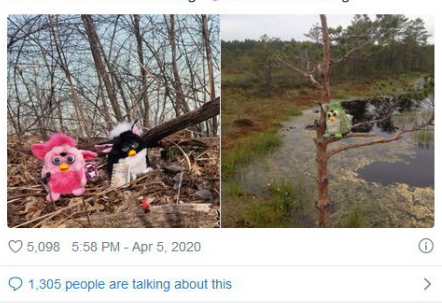

O 183K 7:46 PM - Mar 29, 2020

Q 1,305 people are taking about ths

O 3926 neonle are takno anoutthis

Parodisztikus „mi vagyunk a vírus” mémvariációk.

A kulturális képzelet múköodése szempontjából érthetô, hogy a járványügyi vészhelyzet középpontba kerülése szabadjára engedte azokat a metaforákat, amelyek a némileg háttérbe szorult ökológiai vészhelyzetre a betegség terminológiájával próbálják felhívni a figyelmet. De az sem olyan meglepó, hogy ez a próbálkozás csak viccként tudott igazán érvényesülni, hiszen a vádaskodások árnyékában a (látszólagos) komolytalanság marad az ökológiai búntudat egyedüli kifejezési módja. Mindazonáltal a klímaprobléma antropogén eredetének a kulturális tudatban való bagatellizálása nem kizárólag a probléma elfojtására vagy szublimációjára vezethetô vissza: az 
is szerepet játszhat benne, hogy az ökológiai problémákra használt betegségmetafora az elmúlt 30 évben elhasználódott és közhely lett belôle.

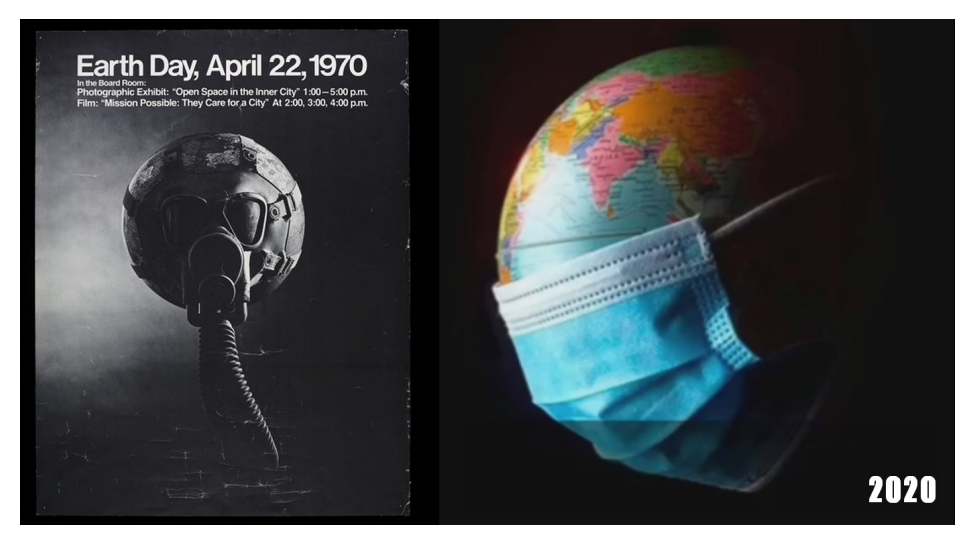

Az 1970-es „A Föld napja” poszter és a szájmaszkot viselö Föld 2020-

ból.

Az 1970-es elsố Föld napját egy olyan poszter hirdette, amelyen a bolygó gázmaszkot visel - a kép az élóvilágot „fojtogató” környezetszennyezésre volt hivatott felhívni a figyelmet. Rachel Carson Néma tavasz címú könyvének (1962) a maga idejében döbbenetes hatására ekkor még elsôsorban a kémiai anyagok felelôtlen felhasználása és az élố rendszerekbe való beszivárgása, illetve az ózonréteg elvékonyodása keltette a legtöbb aggodalmat a Föld sorsáért aggódó lakosság körében. A 2020-as Covid-híreket meglehetôsen gyakran illusztrálták hasonló képpel, amelyen a kék bolygó szájmaszkot visel. Csakhogy az elóbbivel szemben ez a kép a vírus által fenyegetett globális emberiség metonimikus megjelenítését célozza egy olyan vízióval, amely a bolygót és az embereket egyazon oldalon igyekszik egyesíteni az ôket ért külső támadással szemben. Ha a kép utal is a nem-emberi fajokat megtizedelô, ,járványszerú” környezetpusztításra, elsősorban nem erre hívja fel a figyelmet. Nem csoda, hiszen a szóban forgó toposz ekkorra már gyakrabban szült visszatetszést, mint új felismeréseket. A klímakatasztrófa fenyegetését a Web2.0 megjelenése után a reflektorfényre áhítozó felhasználók talán túlságosan is gyakran a „beteg” Föld megszemélyesített képével jelenítették meg, ,aki” hol oxigénmaszkot hord (ami a levegô széndioxid-telítettségére utal) vagy lázas (ami a globális felmelegedést hivatott reprezentálni), a diagnózisa pedig nem más, mint hogy „elkapta az embert”. És bár ez a reprezentáció a maga idejében épp oly fertôzố volt, mint a 2020. áprilisi „mi vagyunk a vírus” mém, végül olyan elterjedtté vált, hogy mondhatni kialakította a koncepcióval szembeni „nyájimmunitást”: a felhasználók többé nem mutatkoztak fogékonynak az így közvetett ökológiai üzenetre. Vagy „passzénak” minôsítették, vagy kikérték maguknak, hogy bármilyen módon felelôsnek volnának tekinthetốk a bolygó állapota miatt. 


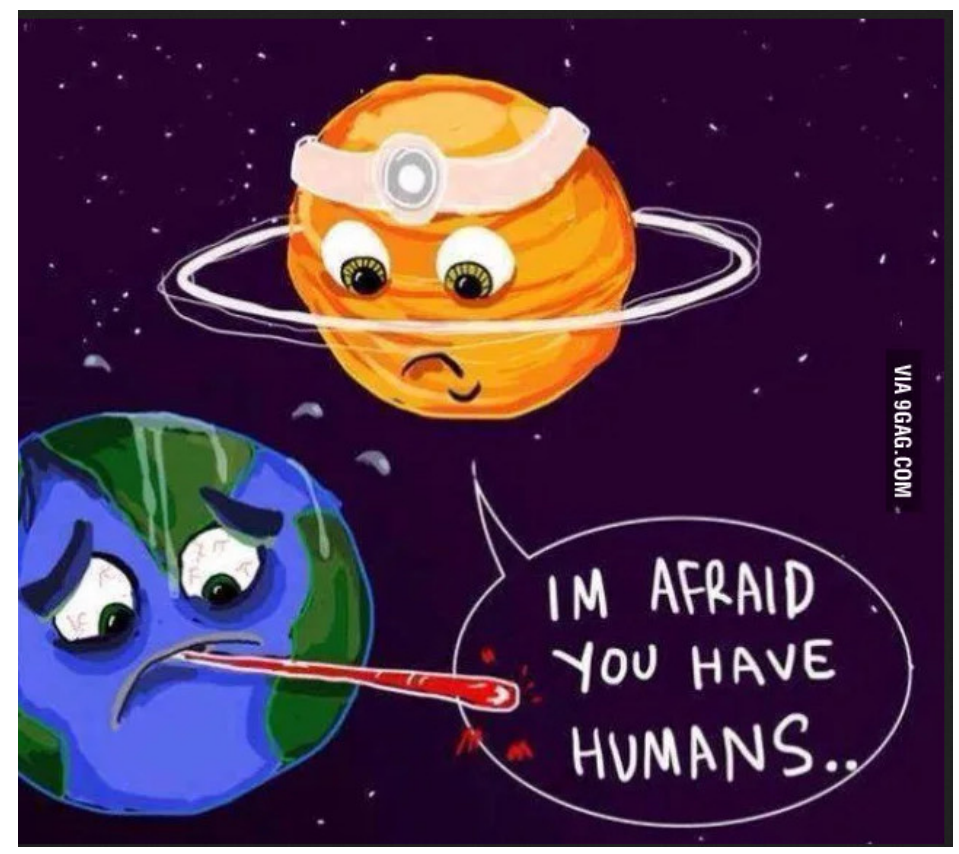

Környezetvédelmi indittatású „Félek, elkaptad az embert” kép a netröl 2014-böl. Forrás:

https://twitter.com/alfredoflores/status/458620639226494976

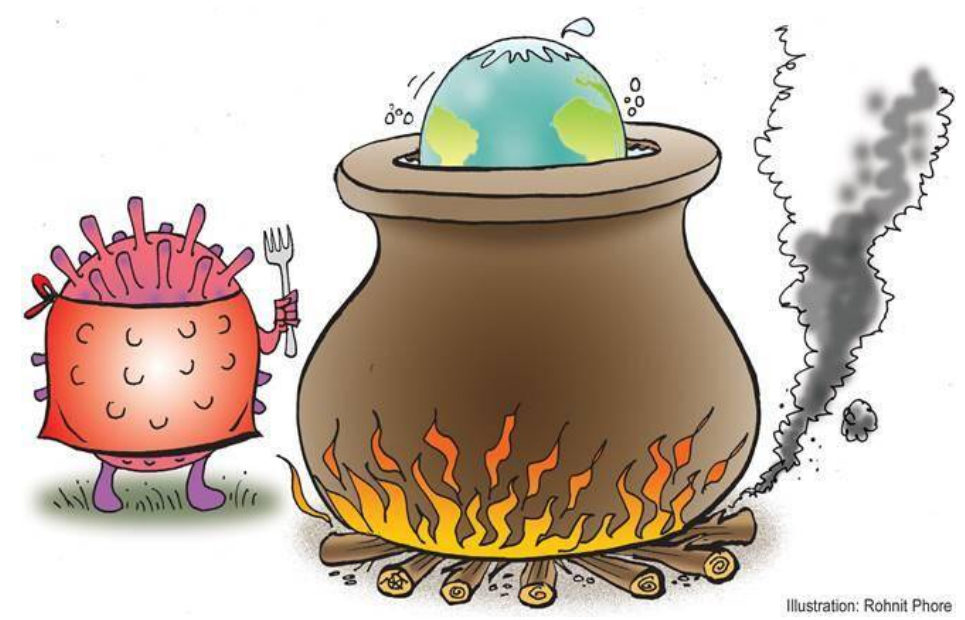

Az antropogén klímaváltozás rásegít, hogy a megváltozott környezetben a kórokozók új gazdatesteket találhassanak.

Illusztráció: Rohnit Phore. Forrás:

https://www.financialexpress.com/opinion/relation-betweencoronavirus-and-global-warming-climate-crisis-changes-diseasepandemics/1883450/

Az ökológiai problémáknak ez a betegségmetaforája mindazonáltal jóval a közösségi média kora elôtt alakult ki. Az ezredforduló elôtt a ponyva és a populáris film volt az a médium, amely a szóban forgó retorika leghatékonyabb terjesztôközegeként múködött. A Robin Cook 1987-es Járvány címú bestsellerébôl adaptált 1995-ös film egy olyan feliratsorozattal fejezôdik be, amely az Ebolát a Föld „védekezô mechanizmusának” a megnyilvánulásaként értelmezi a vírusként pusztító emberrel szemben. A cselekmény önmagában aligha motivál egy effajta ökológiai zárlatot - mely 
elképzelhetetlen lett volna a 80-as évek AIDS pánikja nélkül, amikor a szerzett immunhiány ismert és rettegett betegség lett. Az a fantázia pedig, hogy a Föld maga is ezzel a betegséggel küzd, a sosem teljesen elfeledett organikus világkép hagyománya mellett sokat köszönhet Lovelock tudományos alapozású és ugyanebben az idôben közismertté vált Gaia-hipotézisének, ${ }^{[1]}$ amely a bolygót gigantikus, de „egységes” organizmusként képzelte el - ennek a képzetnek pedig ráadásul egy antromoporf istennô nevét adta. Peter Chatalos 2012-ben így már egy jól kidolgozott fantáziára épített, amikor az ökológiai egyensúly felborulásának magyarázataként azzal a képpel él, hogy a bolygó „immunrendszerének” múködését megbénítja az emberiség kulturális „autizmusa”, vagyis „Gaia az AIDS egy saját verziójától szenved” (Chatalos 2012: 44).

Mondják, a 90-es évek olyan járványfilmjei, mint amilyen a Virus (Outbreak. Wolfgang Petersen, 1995) vagy a Járvány (Virus. Armand Mastroianni, 1995) akkor is az AIDS-ról szólnak, ha a filmben amúgy Eboláról és ahhoz hasonló vírusokról van szó (Ostherr 2005: 182-186.). Valóban, az AIDS afrikai eredetének ismertté válásával szinte kötelezô elem lett a narratíva középpontjában álló betegség afrikai (de mindenesetre harmadik világbeli) előzményeinek a bemutatása (Wald 2007: 32-34.), illetve a betegséget közvetítô (vagy közvetítônek gondolt) majom szerepeltetése. ${ }^{[2]}$ Mivel azonban nagyjából ugyanebben az idôben alakult meg a rohamosan pusztuló esôerdôk és a bennszülött lakosság védelmében életre hívott Esôerdô Alapítvány (The Rainforest Foundation Fund), amelyet az akkortájt rendkívül népszerú énekes, Sting tett prominenssé a köztudatban, ${ }^{[3]} \mathrm{a}$ járványfilmekben szinte magától értetôdônek tûnt az „érintetlen” vidékek ökológiai tönkretételének újonnan a köztudatba került problémáját az „efféle” helyekrôl érkezó járványok megjelenésével összefüggésbe hozni. Amiból könnyen az a következtetés vonható le, hogy a „természeti” népek köréból a Nyugat meghódítására érkezô mikroszkopikus kórokozók voltaképp a civilizáció által sarokba szorított Természet ellentámadásának a képviselői.

Az említett filmekkel egyidejú vagy azokat ihletô populáris irodalom megállapításai nem is kertelnek sokat ezzel kapcsolatban. Patrick Lynch 1995-ös Carriers címú regényének az egyik szereplôje például nem mást jelent neki, mint hogy „Mi nem tartozunk ide (...) Mi vagyunk itt a betegség. Mi vagyunk a vírus. Az erdố tudja ezt." (Vö. Wald 2007: 46) De az 1994-es Halálzónában Preston is igencsak egyértelmú a járvány okát illetôen:

Bizonyos értelemben a Föld immunrendszere védelmi harcot indított az emberiség ellen, válaszul az emberi élősködőre, a burjánzó emberfertôzésre, a betonépítmények halott foltjaira; Európa, Japán, az Egyesült Államok rákos rothadására, ahol nyüzsögnek a sokszorozódó fốemlôsök, kolóniák növekednek, és tömeges kihalással fenyegetik a bioszférát. (...) A Természet különös módon tartja egyensúlyban magát. A Föld immunrendszere felfedezte az emberi faj jelenlétét és beavatkozik. A Föld megpróbálja kiszorítani magából az élósködő embert. Meglehet, hogy az AIDS e tisztulási folyamat elsô hulláma lesz. (337-338.)

Bár nem habozik a Földet antropomorfizálni és „szándékkal” felruházni, Preston a járványokat éppúgy az emberi civilizáció által kiváltott jelenségként, okozatként kezeli, mint azok a tudósok és 
tudománytörténészek, akik éppen ebben az idôben kezdtek népszerú szövegeket publikálni a járványok és az ökológia összefüggéseirôl. Alred W. Crosby 1986-os könyvét követve Jared Diamond 1997-ben írt bestsellert arról, hogy az emberekre veszélyes járványos betegségek az állattenyésztés meghonosításával létrejött közelségnek köszönhetôen evolválódtak úgy, hogy mutálódott formában az emberekre is veszélyesek legyenek (Diamond 2000: 207). ${ }^{[4]}$ Ugyanakkor az efféle „zoonotikus” betegségek kialakulásának valószínúségét az egyre ritkább és egyre távolabb lévố olcsó erôforrások irányába terjeszkedô globális ipar (Moore 2019: 39-40.) hihetetlenül megnöveli, amikor a vírusok hordozójaként szolgáló vadállatokat megfosztja az élôhelyüktôl, minek következtében azok kénytelenek az emberi települések közelében menedéket keresni, ahol a gyakran kisemmizett, szúkölködô lakosok arra kényszerülnek, hogy „olcsó” élelemként üdvözöljék ezeket az állatokat, és így terjesszék tovább a betegséget, ahogyan ez a Covid19 és nagy valószínúséggel számos 20. század végi és 21. század eleji járványkitörés esetében is történhetett (Domschitz 2020). A pozitív visszacsatolások ezen aggasztó folyamatában az antropogén klímaváltozás még inkább rásegít, hogy a megváltozott környezetben a kórokozók új gazdatesteket találhassanak (Bhushan 2020).

Azt gondolhatnánk, hogy Soderbergh 2011-es Fertózés (Contagion) címú népszerú (és a kritikusok szerint járványügyileg a korábbiaknál hitelesebb) filmje volt az első olyan mozgókép, amelynek a zárlata egyértelmúvé teszi a zoonotikus járványok kialakulása és a természeti (és emberi) erôforrások kizsákmányolása közti ok-okozati viszonyt. Azt már a film elején is tudjuk, hogy a történet szerint több mint 20 millió embert megbetegító és több mint 20 százalékos halálozási arányú vírus (amelynek az elképzeléséhez a SARS koronavírus 2003-as bemutatkozása adta az inspirációt) Hong Kongból származik. Az azonban csak az utolsó pár percben derül ki, hogy a vírust hordozó denevéreket a honos ôserdő (feltehetôen ipari vagy mezôgazdasági célú) kiirtása tette otthontalanná és késztette arra, hogy a nagyvárost ellátó nagyipari sertéshizlaldában telepedjenek meg, átadva a vírust egy malacnak, amelyiknek az elfogyasztására tett elókészületek azután a zéró páciens végzetes megfertôződéséhez vezettek. Ami hagyján: az éles szemú nézô arra is rádöbbenhet, hogy az ôserdô kivágását végzô gépek (a rajtuk levô logo alapján) pontosan annak a cégnek a tulajdonát képezik, akiknek az említett „zéró páciens” dolgozott. A járvány mint Isten büntetésének klasszikus trópusa itt ökológiai Nemesissé válik - mintegy annak részeként, amit James Lovelock 2007-es könyvében Gaia Bosszújának nevezett. Ugyanakkor ez a koncepció és a mögötte álló „felismerés” még a filmiparban sem annyira újkeletú, mint ahogy esetleg tûnik. 


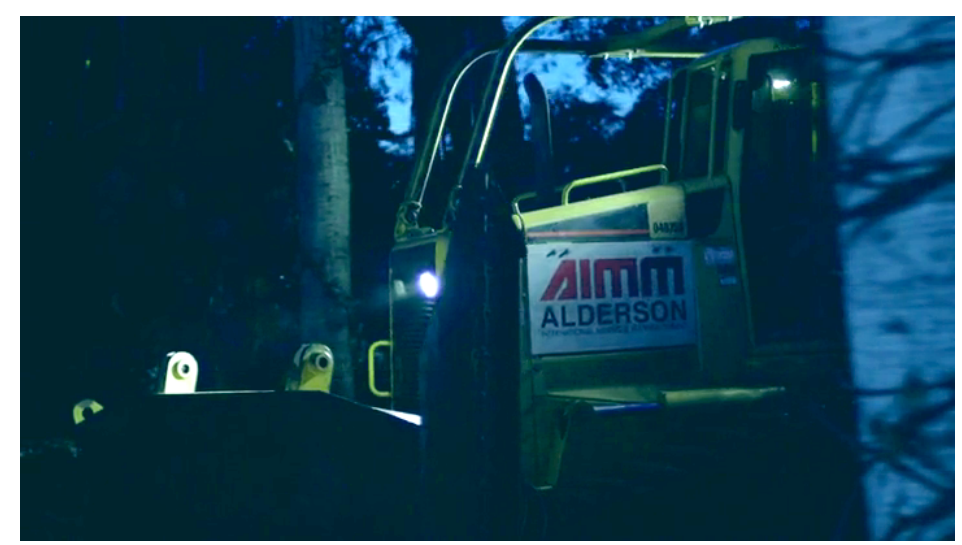

A zéró páciens által képviselt cég logója a vírusgazda denevérek elüzéséért felelös buldózeren a Fertözés cimú filmben (Contagion.

Steven Soderbergh, 2011).

\section{A vírus mint öko-Nemesis}

A Michael Crichton 1971-es regényéból készült Az Androméda-törzs (The Andromeda Strain. Robert Wise, 1971) egy múholdról érkezett vírus garázdálkodásáról szól, amely egy egész falut kiirt, mielôtt az Egyesült Államok legkitúnôbb kutatói el nem kezdik vizsgálni egy erre a célra felszerelt állami intézményben. A film egyáltalán nem tematizálja az ökológiát (vagy a környezetvédelmet, ahogyan annak idején elsôsorban nevezték, a laborkísérletek során azonban az derül ki, az úrból származó halálos kórokozó abban a kultúrában növekszik a leginkább, amelyben a legmagasabb a széndioxid-koncentráció és erôs az ibolyántúli sugárzás (mely a film megalkotása idején a globális felmelegedés egyik legaggasztóbb hatásának tûnt). Másképp fogalmazva, bár errôl egy szó sem esik a filmben, a vírus a tönkretett környezetben terjed leginkább. ${ }^{[5]}$ Mondhatnánk, hogy a film azt sugallja, hogy „a baj csôstül jön”, vagy „a szegény embert az ág is húzza”, a vírus viselkedése azonban az ökológiai film (késóbbi) hagyományát ismerve inkább sugallja azt, hogy „ki mint vet, úgy arat”.

Ami az aratást illeti, ez a metafora az 1979-es No Blade of Grass (Cornel Wilde) címú filmben szó szerint veendô, mivel ez egy olyan apokaliptikus járványhelyzetrôl szól, ahol a betegség nem közvetlenül az emberiséget, hanem a gabonát sújtja. Pontosabban a fúféléket pusztítja el (a rizst is beleértve), amelyek azután a növényevô állatokat is megbetegítik - ami globális éhínséget okoz és zavargásokhoz vezet, mígnem az egész világ anarchiába nem süllyed, ahol azután valóban csak az erôsebbek maradhatnak életben. Bár a film elsôsorban a túlélésért való küzdelem nehézségeirôl szól, az ökológiai vészhelyzet nem „véletlenszerúen” választott ürügy a posztapokaliptikus borzalmak megjelenítéséhez. A fúfélék (gabonafélék) az emberiség élelmezésének valóban nagy részéért felelôsek, ami még nagyobbá válik, ha hozzávesszük az állattenyésztéshez felhasznált takarmánynövényeket is. A gabonafélék „kihalása” tehát legalább akkora gondot okozna, mint a méheké, és sajnos hasonlóképpen lehetséges is. Az utóbbi százötven évben jellemzóvé vált monokulturális mezőgazdaság ugyanis igen sérülékeny, és szinte felkínálja magát a kórokozóknak 
(Foster 1999: 94, Takács-Sánta 2004: 210). A termények korábban jellemzó sokféle helyi verzióit ugyanis a nagyipar és a globális kereskedelem igényeinek megfelelôen néhány nagy hozamú fajtára cserélték le, amelyek általában kevésbé ellenállóak a betegségekkel szemben. Ráadásul, mivel nagy tömegben és szorosan egymás mellett találhatók, a fertôzésnek semmi sem szab gátat - a növényvilágban ,járványhelyzetben” ugyanis az adott betegségre nem érzékeny, idegen genushoz tartozó fajták biztosítják a „szociális távolságtartást”.

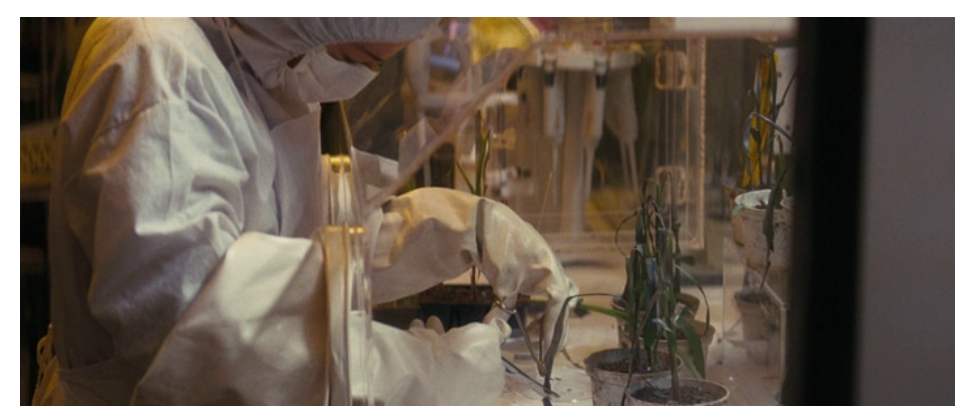

A kukoricafertôzést vizsgáló tudós a Csillagok között cimü filmben

(Interstellar. Christopher Nolan, 2014).

A 2014-es Csillagok közt ((Interstellar. Christopher Nolan, 2014) egy pontosan ilyen fenyegetés valóra válását mutatja be, hiszen egy olyan világot ábrázol a közeljövốbe extrapolálva, amelyben egy gombafertôzés következtében a búza már az egész földtekén elpusztult, és a kukorica is kezd elbukni a kórokozókkal vívott küzdelemben. Bár nyilvánvaló, hogy a gomba ilyen szintû elterjedéséért a termesztés módja és az (antropogén eredetû) klímaváltozás lehet a felelôs, a film ilyen irányú finom utalásai már csak azért sem hangsúlyosak, mert a narratíva értelmében pontosan az a technológia hozza el a megváltást, amely ezt a helyzetet eredményezte. A 35 évvel korábban készült No Blade of Grass viszont már vagy még nyíltan állítja, hogy a vírus elterjedése annak köszönhetô, hogy „a 70-es évek elejére az ember olyannyira tönkretette már a környezetét, hogy onnan már nehéz volt a visszatérés. Természetesen sokat beszéltek a Föld megmentéséról, de a valóságban nagyon keveset tettek." A bekövetkezô járvány elején még csak a harmadik világ népessége kezd éhezni - amelyrôl egy nyugati étteremben vetített filmhíradóban látunk tudósítást, miközben a nézôk teljes lelki nyugalommal szedik púposra a táljaikat a svédasztalon feltálalt sonkából és más zsíros falatokból. A hírekben ezt követően a következó diagnózist közlik: „a Világökológiai Vészhelyzeti Bizottság arra az egyöntetú véleményre jutott, hogy a szennyezô anyagoknak és a vegyszereknek a talajban és az atmoszférában való felhalmozódása a fúbetegség kiváltója”. 


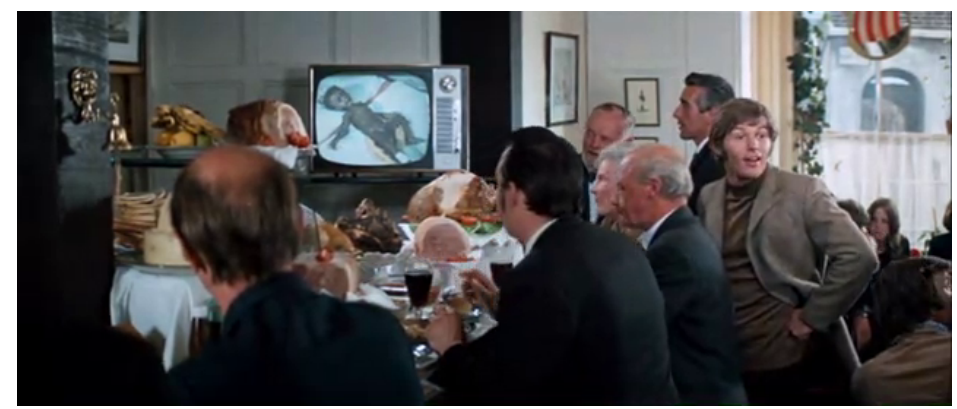

A fübetegség által okozott éhínségról szóló híreket hallgató britek a svédasztalnál a No Blade of Grass címú filmben (Cornel Wilde, 1970).

Míg a No Blade of Grass elsôsorban a nyugati túlfogyasztást és a jólétnek a centrum-periféria szerinti megoszlását kritizálja, az egy évvel késôbbi, német gyártmányú Hamburgi betegség (Die Hamburger Krankheit. Peter Fleischmann, 1979) az urbanizáció és a technokrata szemlélet életellenességében látja azt a hübriszt, amelynek a járvány a büntetése. A halálos fertôző betegség kiváltó okáról valójában semmit nem sikerül kideríteni, a fôszereplố azonban, akinek a véleménye már csak azért is megfontolandónak tünhet, mert orvos, a következô parabolával próbálja megvilágítani a betegséggel kapcsolatos megérzését:

Vegyünk egy patkányt, és tegyük be egy túl kicsi ketrecbe. Etessük össze-vissza, tartsuk hidegben, de a patkány túléli. Most legyen a ketrec még kisebb, a hômérséklet még alacsonyabb, mérgezzük meg az ételét fém nyomelemekkel, ólommal, higannyal, és a patkány továbbra is túléli. Adjunk neki mérget még nagyobb dózisban és legyen a hômérséklet még alacsonyabb, világítsuk meg villódzó fénnyel, ami tönkreteszi a napi élettani ritmusát, majd idegesítsük folyamatos, magas hangokkal, és a patkány egyszerre csak megdöglik. Vajon mi ölte meg?

A kérdés költői - de nem azért, mert a választás lehetetlen, hanem inkább azért, mert az „okok” így felsorolt együttese nagyon is sokatmondó, többet mond együtt, mint a részek külön-külön, hiszen a környezetpusztításnak az emberre való visszahatásait sorolja fel. Késôbb egy másik enigmatikus megjegyzéssel is találkozunk, miközben a túlélốk a járvánnyal sújtott városokat messze elkerülve, a természetben kóborolnak. „Már nem mi vagyunk a világ urai”, hallhatjuk a narrátori hangot egy bukolikus beállítás alatt - ami azt sejteti, hogy a járvány „oka” nem más volt, mint maga az élólények egymásrautaltságát semmibe vevô antropocentrizmus; a vírus pedig mintegy „ráncba szedte az emberiséget, megmutatva ennek az elképzelésnek az illuzórikusságát.

Az 1995-ös Virrus ezeknél a filmeknél jóval kisebb érdeklődést mutat az ökológiai problémák iránt, jelezve, hogy az ezirányú érzékenység - vagy fogékonyság - idôközben igencsak lecsökkent. [6] Éppen ezért figyelemreméltó, hogy az Amerikát fenyegetô járvány kiindulópontjaként bemutatott afrikai törzs varázslója szerint a fertôzés azért tört ki, mert „a fairtással az emberek felzavarták az isteneket az álmukból. Az istenek megharagudtak. És ezért a járvány a büntetés.” A mágikus világnézetre utaló kifejezések ugyan könnyen felidézhetik a „babonás fekete - felvilágosult fehér” rasszista ellentétpárját, a dialógusban azonban ennél több rejlik, ha ahelyett, hogy arra 
fókuszálunk, hogy ki osztja a „büntetést”, azt figyeljük, hogy miért jár, ha valóban jár.

A vírusnak a bolygó „immunsejtjeként” és/vagy a neki kárt okozó emberek biológiai

„büntetéseként” való elképzelése az ezredforduló után az ökoterrorizmus kérdésével foglalkozó filmekben vett új irányt. A Járvány és a Vírus évében bemutatott 12 majomban (12 Monkeys. Terry Gilliam, 1995) a világvégét okozó laborasszisztens nem azért eresztette szabadon a vírust, mert ezzel állatokat akart menteni, ahogyan azt a fôszereplő feltételezte. Ez a hamis feltételezés azonban a fiktív bioterrorista mellett számos filmrendezônek ötletet adott, hiszen azt sugallja, hogy a kórokozók adott esetben szándékosan is bevethetôk a Föld „megmentése” érdekében amihez a népesség megtizedelése úgyis elengedhetetlen. A kémiai környezetszennyezés, az üvegházhatás és az ózonpajzs gyengülése által jelentett fenyegetés mellett a 20. század harmadik felében a túlnépesedés is a világ élhetôségét veszélyeztetô legfốbb problémák közé sorolódott. ${ }^{[7]}$ Nem csoda tehát, ha a klímaválság problémájára való reflexió a 9/11 utáni filmekben, amelyek természetesen gyorsan lecsaptak a terrorizmus témájára, ${ }^{[8]}$ gyakran a bioterrorizmus fenyegetéseként jelenik meg. A Dan Brown regényéból készült Infernón (Ron Howard, 2016) és az Utópia címú minisorozaton (Utopia. Dennis Kelly, 2013-14) kívül az ökológiai válsághelyzet által megkövetelt biopolitikai célzatú és biotechnológiai eszközökkel kivitelezni kívánt populációkorlátozás a Helix sorozat (Ronald D. Moore, Lynda Obst, Steven Maeda, Brad Turner, 2014-15) 2. évadának is az egyik legfontosabb problémaköre.

A vírus itt nem csak a „ritkításért” felelős, hanem az emberi faj egy új transzhumán mutációjának a kialakításáért is. ${ }^{[9]} \mathrm{Az}$ új faj tagjai örökké élnek, s így vélhetôen nagyobb felelôsséggel viseltetnek a tetteikért, mint az átlagemberek, akiket „rövid” életük arra késztet, hogy intenzíven kihasználják a környezetük által nyújtott lehetôségeket. A halhatatlan mutánsok ezzel szemben nem háríthatják át „környezeti adósságukat” a következô generációkra (vö. Jamieson 2008: 191, Kovács 2008: 82). Mivel azonban elég „felsôbbrendúnek” gondolják magukat ahhoz, hogy eldönthessék, ki éljen és ki haljon, valójában ugyanazt az antropocentrizmust gyakorolják „emelt” szinten, mint ami az emberiségnek a nem-emberi világhoz való viszonyát eleddig meghatározta. A második évad azzal fejezôdik be, hogy a halhatatlanná vált fôhoósnô rádöbben: az „egyszerư” emberek problémáira aneszteziáló hatást gyakorló örök élet voltaképpen egy betegség - és egy újabb vírus rá a gyógyszer, amely az eladdig minden kórra immunis halhatatlanokat is megöli.

Mint látható, a vírusok ökológiai „gyógymódként” való elgondolása a bolygó „betegségére” ekkor már bevett narratív elem volt. Az 1999-es Mátrixban (The Matrix. Lana Wachowski és Lilly Wachowski) nem ez a gondolat a narratíva középponti eleme, de minden bizonnyal ez a film egyik legtöbbet idézett kinyilatkoztatása. Az öntudatra ébredt Mesterséges Intelligencia virtuális ökoszisztémájának a védelmére kirendelt - tehát (kezdetben) bizonyos szempontból a digitális organizmus immunrendszeréért felelős - Smith ügynök-program ugyanis így fejezte ki a hús-vér emberekről alkotott lesújtó véleményét:

Ráébredtem, hogy önök valójában nem emlősök. Minden emlős ezen a bolygón ösztönösen természetes egyensúlyra törekszik a környezetével. Kivéve magukat, 
embereket. Letelepednek valahova és addig szaporodnak, míg fel nem élik mind a természeti erőforrásokat. És azután csak úgy képesek fennmaradni, ha új területeket foglalnak el. Van egy másik organizmus is ezen a bolygón, amely ugyanígy viselkedik. Tudja melyik? A vírus. Az emberi faj egy betegség, egy ragály. És mi vagyunk a gyógyszer.

Innentôl már csak idô kérdése volt, hogy az ökomizantrópia említett két narratívája mikor találkozik össze a filmben is - ami az 2014-es Kingsmanben (Kingsman: The Secret Service. Matthew Vaughn) történt meg. Az ember mint vírus képzete és a vírus mint büntetés gondolata itt közvetlenül is a klímaválság témájához kapcsolódva jelenik meg az embert mint vírust elpusztító vírus mint vakcina ökoimmunológiai allegóriájának formájában:

Ha Ön elkap egy vírust, belázasodik. És azért emelkedik a testhômérséklete, hogy elpusztítsa a vírust. A bolygó ugyanígy múködik. A felmelegedés maga a láz, az emberiség pedig a vírus. Mi betegítjük meg a bolygót. A selejtezés az egyetlen reményünk. Ha nem kezdjük el csökkenteni a lakosságot, az csak kétféleképpen végződhet. A test végez a vírussal, vagy a vírus végez a testtel. Akárhogy is... az eredmény ugyanaz. A vírus elpusztul.

Bár a „selejtezés” projektje, mint láttuk, nem elôször kerül elô a túlnépesedés radikális és erôszakos megoldásaként (aminek a problematikusságát jól jelzi, hogy a Mátrixhoz hasonlóan itt is az antagonista az, aki megfogalmazza), eddig általában nem gyógyszerként és különösen nem „vakcinaként” utaltak rá, ahogyan a Kingsmanben. Mindenesetre ez a fejlemény valószínúleg elegyengette az utat a cinikusabb közösségi oldalakon „boomer removerként” is emlegetett Covid19 effajta szerepben való elgondolhatósága elôtt (Hoffower 2020; Tenbarge 2020) különösen, hogy Greta Thunberg hatására az is tudatosult, hogy éppen ez a háború után született nyugati „boomer”-nemzedék okolható leginkább az ökológiai problémák kritikussá válásáért, vagy legalábbis azért, mert a problémák ismeretében sem tettek azok súlyosbodása ellen (vö. Bosselmann 2019). Utólag egyébként az is jól látható, hogy a film nem csak a 2020-as „Mi vagyunk a vírus" mémnek, de annak a médiahype-nak is megágyazott, miszerint Bill Gates csakis azért ügyködik annyira a koronavírus elleni vakcina kifejlesztésén és a WHO megsegítésén, hogy a Kingsman milliárdos antagonistájának a mintájára ennek a segítségével tizedelje meg a túlnépesedett emberiséget; vagy tartsa ellenôrzés alatt az esetleges károkozó tevékenységeiket a vakcinával befecskendezett nanochipek segítségével (Joyce 2020). 


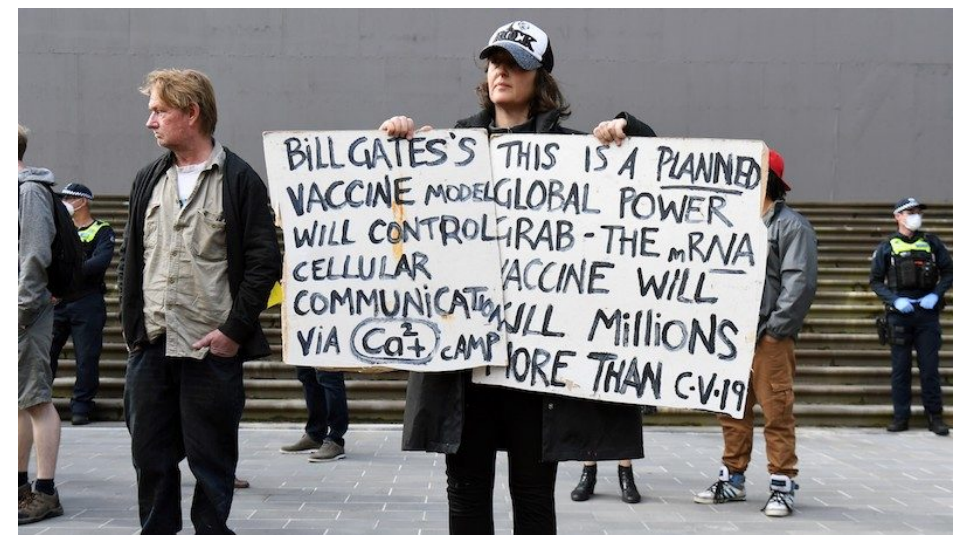

Oltásellenes aktivista tiltakozik Bill Gates inditványai ellen

Ausztráliában 2020. május 10-én (fotó: William West/AFP via

Getty Images).

A Kingsman és a Covid-járvány közti hat évben mindazonáltal nem csak a mémek biztosították annak a metaforának a túlélését, amelynek értelmében az emberiség a Föld ökológiai „betegségének” az okaként tételezôdött. A klímaválság problémáját nyíltan megszólító 2019-es Godzilla II - A szörnyek királyában (Godzilla: King of the Monsters. Michael Dougharty) az ökoterroristává vált tudós fốszereplônô a következô - s a történet által egyébként teljességgel igazolt - értelmezéssel áll elô a prehisztorikus óriásszörnyek felbukkanásáról:

Többezer éve az emberek uralják a Földet, és tudjuk hová vezetett ez. Túlnépesedés, légszennyezés, háborúk. A tömeges kihalás, amitôl tartottunk, már elkezdődött. És mi idéztük elő. Mi vagyunk a fertôzés. A Föld, mint minden más élô szervezet lázzal küzd a fertôzés ellen. Ezért jönnek most eredeti, jogos urai, a Titánok. Ôk a Föld természetes védelmi rendszere, hogy megóvják a pusztulástól, és egyensúlyt teremtsenek.

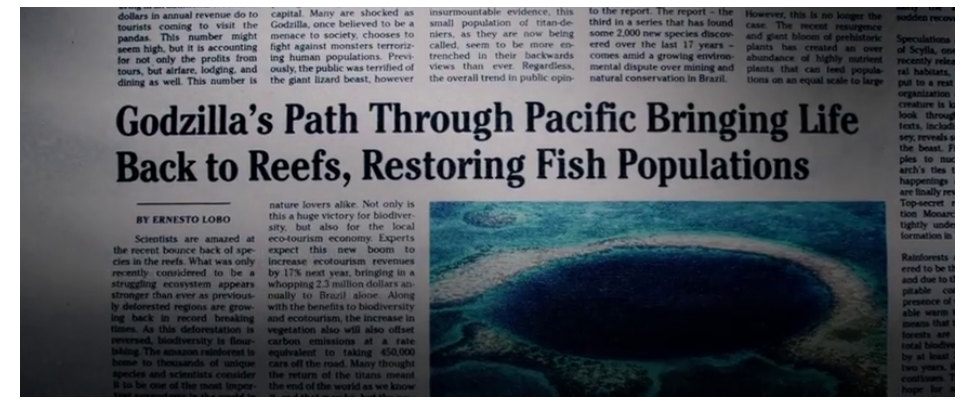

A Godzilla II (Godzilla: King of the Monsters. Michael Dougharty

2019) levezetô képsorain fiktív újságcikkek láthatók, amelyek a szörnyek nyomán megújuló természetról tudósítanak.

\section{Fertôző szörnyek}

Bár az nem túl gyakori, hogy a populáris fikciókban oly kedvelt szörnyek az ökológiai „,vakcina” szerepét kapják, az annál megszokottabb, hogy a szörnyeket ezek a filmek valamely vírus 
hatásaként mutassák be, ez pedig olykor a fentiekhez hasonló ökológiai implikációkkal bír. A vírusok révén történô népességkorlátozás az 1980-as Hell of the Living Dead (Bruno Mattei) címú zombifilmben is megjelenik, amely láthatóan úgy próbálta lefölözni a 12 évvel korábbi $\mathrm{Az}$ élôhalottak éjszakája óriási sikerét, hogy a harmadik világ élelmezésének és a világ eltartóképességének az ekkor igencsak idôszerünek tekintett problematikájával turbózza fel a zombijárvány fenyegetését. A film története szerint egy laborban baleset történik, és egy kiszabadult anyag zombivá változtatja a labor dolgozóit - akik azután tovább „fertôzik” a környezô lakosságot, azaz Pápua-Új Guinea bennszülötteit. Ugyanis, mint kiderül, a labor a világ e távoli szegletében található, nem véletlenül. Nem az olcsó munkaerô miatt, amire még visszatérünk. 1980-ra a nyugati világ már egy ideje a gazdasági fejlődésben lemaradt, ám annál szaporább harmadik világ megsegítésének szükségességéról és annak megfelelő módjáról vitatkozott (aminek többek közt a már említett, meglehetôsen kétértelmú zöld forradalom is köszönhetô). Garret Hardin ennek kapcsán tette közzé „a közlegelôk tragédiájáról” írt nagy hatású értekezését 1974ben, mely szerint az ökológiai válság megoldását a harmadik világ szaporodási rátája lehetetleníti el (2005: 122). A film ezekre a kortárs (de máig visszhangzó) vitákra reagál a csattanó révén: ugyanis csak a film végére derül ki (bár utalások révén már korábban is sejthetô), hogy miközben a szóban forgó „kutatóközpontokat az emberiség javáért hozták létre, hogy segítsék a fejlődő országokat”, a terv kidolgozói valójában egészen másban mesterkedtek:

az igazi ok rettenetes és hihetetlen. Arra kerestek megoldást, ami a fejlett országokat gyötri a leginkább, s ami nem más, mint a világ túlnépesedése. Meg kell szabadulni a gyenge láncszemektôl, a legvédtelenebbektôl, akikbôl a legtöbb van, a lehetô legegyszerúbb módon. Csak el kell intézni, hogy megegyék egymást.

Ha más erénye nem is igen van, a Hell of the Living Dead az egyik legkorábbi film, amely hangot adott a (vírus révén történô) ökológiai célzatú „selejtezés” gondolatának. Sốt, a témát feldolgozó filmek többségénél jóval egyértelmúbben érzékelteti azt is, hogy a „Mi vagyunk a vírus” mantra sok esetben eufemizmus, és a faji jellemzőinkre való „általános” hivatkozás valójában azt leplezi, hogy „Ôk a vírus” - vagyis ez esetben a harmadik világ lakossága, amely már csak azért is veszélyes, mert a nyugatihoz képest egyre csak nô, és azzal fenyeget, hogy el(v)eszi előlünk a világ erôforrásait. ${ }^{[10]}$ Nem véletlen, hogy a filmben mindezt éppen a zombi figurájával jelenítik meg. Elvégre is ez a szörny az elmaradott gyarmati világ a terméke, amely 20. század eleji fikciókban és filmekben a woodoo varázslattal munkára fogott haiti rabszolgákra utalt, ${ }^{[11]}$ manapság pedig újra egyre gyakrabban asszociálódik a vegetatív funkcióikra való korlátozódásra kényszerített és az egészségügyi ellátástól megfosztott, $\mathrm{s}$ a betegségeknek egyértelmúen jobban kitett szociális páriákkal (Bishop 2010: 71-73.); [12] tehát a mélyszegénységben élôkkel, a hajléktalanokkal, vagy éppen a migránsokkal, akik más szempontból is régóta a kórokozókkal és a fertôzéssel kapcsolódnak össze a kulturális képzeletben (Ostherr 2005: 22, Wald 2007: 6, Woo 2016: 199-201.), ahogyan ez egyébként a Covid kapcsán is megmutatkozott (Este 2020; Pianigiani and Bubola 2020; Foresti 2020). Ráadásul a migránsokról kialakult kép szerint azok éppen úgy tömegben vándorolnak, mint a zombik, akiket például a Walking Deadben „kószálóknak” nevez a fôhôsök 
csapata, s akikre ennélfogva a fertôzéstôl való félelem figuratív módon könnyedén áthelyezhetô. A Z. világháború (World War Z. Marc Forster, 2013) egyik legemlékezetesebb jelenete, amikor a zombik gondolkodni nem tudó, érzelemmentes és csupán az ösztöneiktől vezérelt hordája megtámadja, majd áttöri Jeruzsálem városfalát, hogy táplálkozzon, majd rémisztố gyorsasággal magához hasonlókat gyártson - ami egyszerre imitálja a vírus szaporodását és fertôzóképességét (Sartin 2019: 41-43.). Ugyanakkor az itt látható óriási fal

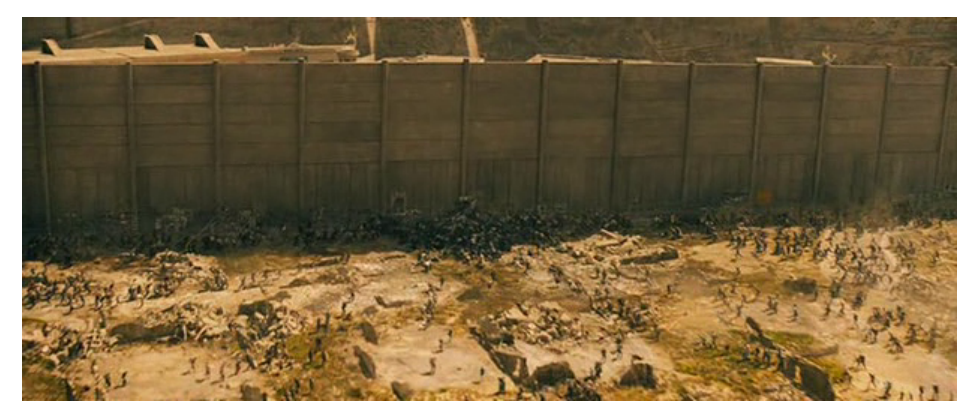

Gyülekezô zombik Jeruzsálem falánál a $Z$ világháború címú filmben

(World War Z. Marc Forster, 2013)

igencsak ismerôs a kortárs zombifilm nézôjének: a déli határán keresztüli inváziótól félve az Egyesült Államok éveket és milliókat ölt a Mexikót az USÁ-tól elválasztó határfal megépítésébe és fenntartásába, és a palesztinokkal való nem szúnố konfliktusa Izraelt is erôdített kerítések folyamatos építésére ösztökéli. (Carrington 2016: 24)

A zombifilm, úgy tûnik, igen kitûnô terepnek tûnik a mikroszkopikus kórokozók és a nem kívánatos embercsoportok közt érzékelt analógia látens és áttételes kifejezésére - az élôk élőhalottá való transzformálása révén. Érdekes, hogy még mielôtt bármit is tudtak volna a vírusról a történelem során - amelyrốl ma gyakran elhangzik, hogy nem halott, de tudományos értelemben nem is él -, szörnyekkel és ezen belül is leginkább élőhalottakkal jelenítették meg a pusztítását. Bár azt gondolhatnánk, hogy a modern tudományos gondolkodás feleslegessé teszi a betegség efféle allegorikus ábrázolását, mégsem így történt, ahogyan azt a 80-as évek sikeres vámpírfilmjeinek (például az Elveszett fiúk (The Lost Boys. J. Schumacher, 1987), vagy az Alkonytájt (Near Dark. Kathryn Bigelow, 1987) könnyen dekódolható HIV utalásai igen jól mutatják. Ami azt illeti, Pasteur 1885-ben adta be az elsô veszettség elleni vakcinát, a vérfarkas-fikciók viszont (amelyek hagyományosan nagy valószínúséggel éppen ezt a betegséget jelenítették meg) épp ekkortájt kezdtek divatba jönni. A saját magán kísérletező orvos Dr. Jekyll Mr. Hyde-dá való átalakulásának 1886-ban megírt története, majd az 1897-es Drakula, amelyben a vámpírvadászként elhíresült Van Helsing vérátömlesztéssel próbálja gyógyítani a vámpírkórt, éppen a modern bakterológia és virológia kialakulásával egyidejüleg kötötte le a közönség figyelmét. [13] És könnyen lehet, hogy az az újabb narratív klisé, amely a klasszikus szörnyek felbukkanását úgy „modernizálja”, hogy vírusfertôzés következményeként azonosítja ôket, valójában nem új alapra helyezi a klasszikus rémségeket, hanem csak a régi értelmezést aktualizálja kissé.

A vámpírfilmek például elsôsorban a (megmagyarázhatatlanul) vonzó idegenektôl való elbódulás 
ellen próbálják „beoltani” a közönséget, ami azt sugallja, hogy a figura valószínúleg a szexuális úton terjedô betegségek reprezentációjaként (is) szolgált - míg a 20. század végén az AIDS-rôl, a 19. században még a szifiliszról mesélt. A kór ezúttal is az elmaradott peremvidékról érkezik a centrumba: Drakula az angol gazdasági érdekeknek az elmaradott vidékek (ezúttal Erdély) iránti érdeklôdése következtében jut Londonba. Emellett meglehetôsen érdekes, hogy éppen a Covid19 kapcsán genetikailag oly kitûnô vírushordozónak minôsített denevérrel hozzák kapcsolatba. A hagyományosan (bár nem mindig) „lassúnak” ábrázolt és egyesével könnyen elkerülhetô, tömegben azonban meglepően gyorsan lehengerlôvé váló zombik megjelenítése esetében inkább a tömeges helyek kerülése és a „véletlen” érintkezéstôl való tartózkodás a hangsúlyos. A zombifilm a szociális távolságtartás fontosságának valóságos oktatófilmje. Vagy inkább a kórokozókkal való „küzdelem” és a szociális távolságtartás szélsôségeit képviseli? Az biztos, hogy a szörnyfilmben a fertôzés továbbterjedésének megakadályozására a „beteg” cserbenhagyása vagy gyors és lehetôleg érzelemmentes megölése az egyik leghatékonyabb és egyszersmind leggyakoribb módszer.

Szemben a Covid19 járvánnyal, amely alatt igyekeztünk elhinni, hogy nem (a) Mások ellen, hanem másokért védekezünk, és szemben a legtöbb járványfilmmel is, ahol a fókusz szinte mindig az önvédelem és a másokon való segítés közti dilemmára kerül, az önvédelem primátusa a klasszikus szörnyfilmben általában nem kérdôjeleződik meg.

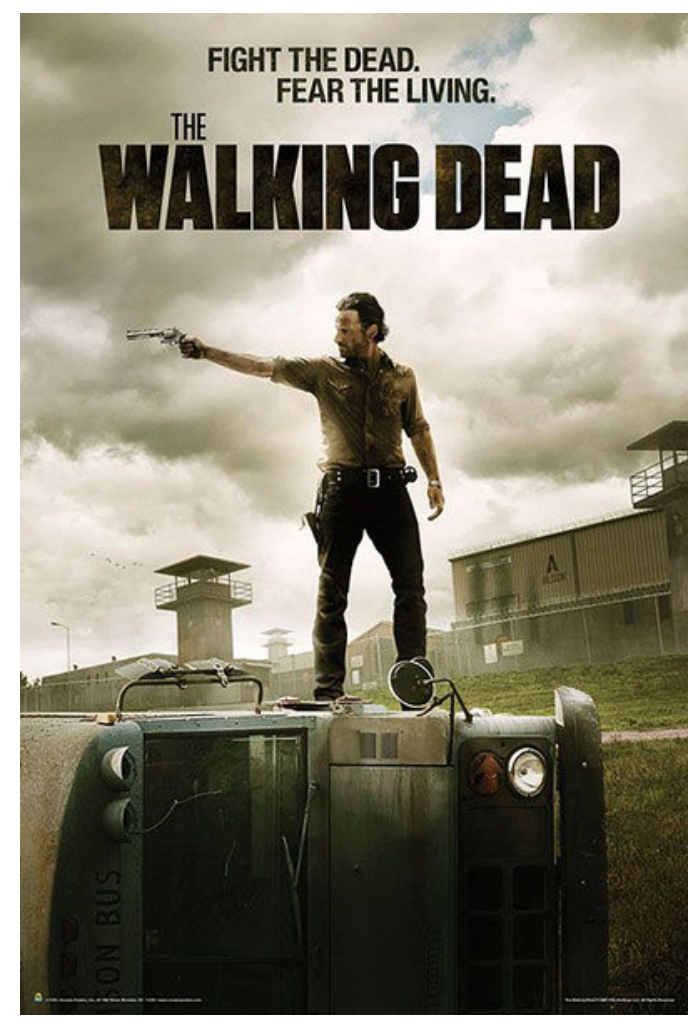

„Harcolj a holtakkal és tarts az élóktôl.” A

The Walking Dead 3. évadának plakátja (TVsorozat. Frank Darabont, Angela Kang, 2010-).

A szörnyfilmek divatossá válása a virológia és az immunológia kialakulásának az idôszakára esik, amely amúgy a kapitalizmus megszilárdulásához szükséges individualizmus és az önérdek 
ideológiai legitimálásának is a daliás korszaka. Mint Yunjin La-mei Woo levezeti, a „fallal” körülvett és a szervezet önálló egységeként felfogott sejt felfedezése és létezésének legitimálása nagyjából párhuzamos a társadalom egységeként felfogott individuum, az önmagát a másikkal szemben meghatározó és attól elkülönülô, homogén karteziánus „én” koncepciójának a paradigmává válásával (2016: 199-201.). Úgy vélték, a társadalom egészségéért ezek a többiektôl különálló, önmagukról gondoskodni képes egységek a felelôsek, aminek az egészség biológiai modelljét is megfeleltették. A biológiai, immunológiai „én” eszerint politikai koncepció - amelyet a szörnyfikciók és a szörnyekkel harcoló egészséges hősök heroikus küzdelme erősít meg a kulturális képzeletben.

Talán nem véletlen, hogy a Hamburgi betegségben éppen az archetipikus kereskedôként feltüntetett szereplô gondolja úgy, hogy a járvány úgy is felfogható, mint „egy tisztulási folyamat. A természet segít magán, csak az erôsek maradhatnak életben. Mi a neve? Természetes szelekció!” Az „erôsebb gyơz" gondolata az evolúció fejlődésként való elgondolásával és az önmagát a semmiből megteremtố racionális (azaz számító) individuum ideáljával egyetemben nem véletlenül a kapitalizmus hôskorából származik: az elképzelés tökéletes kifejezése annak a közgazdaságban és a politikában is kifejezôdô ideológiának, mely az önérdeket azonosítja a társadalom érdekével. A kevésbé leleményesek, kevésbé önzók gazdasági kizsákmányolását és az elesettek cserbenhagyását nem tartja elítélendônek, sốt egyenesen bizonyítékokat sorakoztat arra nézvést, hogy a láthatatlan kéz beavatkozásának köszönhetôen ez a viselkedés a köz javát szolgálja. Bízvást állítható tehát, hogy a szörnyfilm által képviselt betegségkoncepció - amely a zombifilmre is jellemző alapvetôen a szabadpiaci kapitalizmus ágendájára épül. Az ennek megfelelô ideológiai mikroszkópon keresztül nézve pedig nem csoda, ha azok tûnnek a bolygó „kórokozóinak”, akik nem tudnak vagy nem akarnak becsatlakozni a (profit)termelésbe - és akik gazdasági és ökológiai szempontból is a rendszer kárvallottjai (Woo 2016: 199, Attfield 1999: 142, Malm 2019: 193-194.).

Ami azt sugallja, hogy a klasszikus szörnyfilmek ökoimmunológiai szempontból voltaképp az áldozathibáztatás fedôtörténeteit és stratégiáit segítenek megalkotni. Aminek következtében felmerül, hogy ha nem is „mi vagyunk a vírus”, talán nem is „ôk”, hanem inkább egy bárkit befolyásolni képes „fertôzô” gondolat vagy elképzelés (Johnson 2020). Richard Dawkins az effajta „ragadós” elképzeléseket nevezi mémeknek, és a biológiai adaptációra képesítô génekkel szemben ez utóbbiakat tekinti az emberi faj kulturális alkalmazkodóképessége kulcsának - bár hangsúlyozza, hogy ez a fajta alkalmazkodás nincs alávetve az idô próbájának, így könnyen elhibázható. Ennek példájaként a vallási hiedelmeket és babonákat hozza fel - márpedig John Michael Greer szerint az a hiedelem, amely a nyugati világban a 20. század folyamán egyre inkább civil vallássá emelkedett, nem más, mint a végtelen gazdasági haladásba és a jólét fokozódásának a szükségességébe vetett hit (2013: 71-73.), vagyis más néven a kapitalizmus.

\section{„A vírus: a kapitalizmus"}

Nos, a Covid19 kitörése után ez a verzió is hamarosan megjelent a médiában. Ha a vírus egyik 
közvetett hatása a kanálisok tisztulása és a széndioxid-koncentráció csökkenése volt, egy másik, ennél sokkal többeknek feltûnô hatásának az egészségügyi ellátás azonnal érzékelhetô gondjai, az ellátási problémák, illetve a várható gazdasági összeomlás mutatkozott. A baj azonban sokak számára felismerésekkel járt. „Mindez felgyorsítja a már meglévő klímaválságot és a társadalmi válságot. A társadalmi problémák, például a növekvő egyenlôtlenség miatti frusztráció - az Egyesült Államok milliárdosainak kombinált vagyona ugyanis a krízis alatt csak nôtt - egyre intenzívebbé válik" (Schwab 2020).

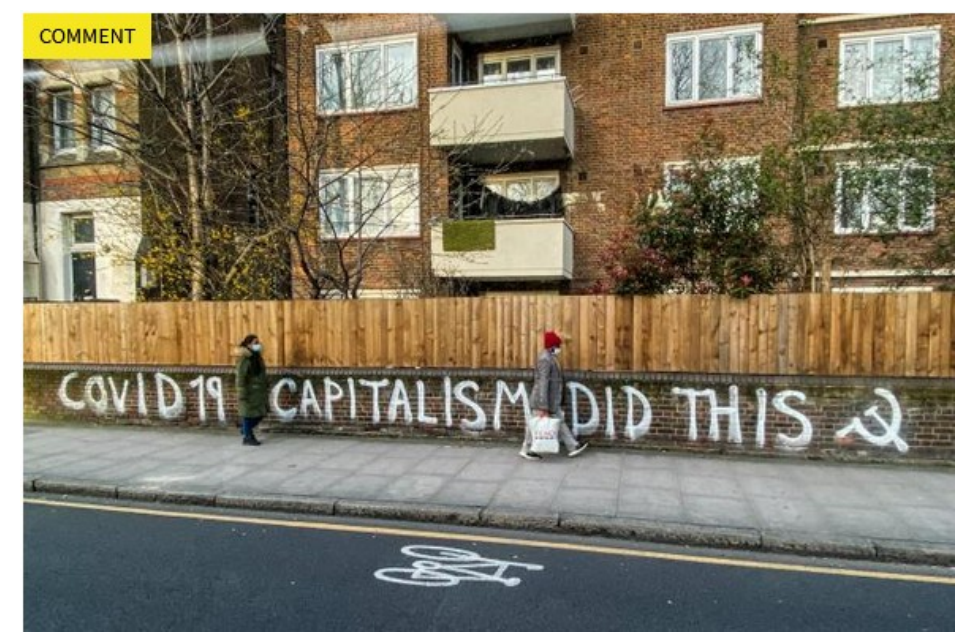

Graffiti a járvány idején. Forrás

https://wwrw.thenational.scot/news/18379478.never-vaccine-cure-

contagion-deadly-capitalism/

Elsók közt éppen az ökológiai válság megoldása iránt elkötelezett kritikusok mutattak rá, hogy a gazdasági válság gyors begyúrúzése és a hirtelen megoldhatatlannak túnô ellátási gondok megjelenése annak köszönhetô, hogy megszakadtak a „hosszú ellátási láncok”, amelyek a globális kapitalizmus jellemzô velejárói. Vagyis annak a tünetei, hogy a termékek előállításának és fogyasztásának a helye - a termelésnek az olcsóbb erőforrások és munkaerô irányába való, s a politikai szabályozás segítségével akadálytalanná tett áttelepítése következtében - egyre távolabbra került egymástól (Vö. Dobos 2020; Gonçalves 2020). Sajnos azonban a vírusok terjedésének ez a hosszú ellátási lánc legalább olyan kedvezô, mint a nagyvállalatoknak (Ostherr 2005: 1).

A kapitalizmus globálissá válása idején a járványfilmek is egyre bátrabban mutattak rá nem csak a könnyú és gyors terjedés szóban forgó veszélyére, hanem az emögött álló erôk gazdasági/politikai meghatározottságaira is. Az 1995-ös Vírusban az afrikai varázsló a vírust a favágással hozza összefüggésbe, és bár ez cseppet sem hangsúlyos, egészen biztosak lehetünk benne, hogy nem a bennszülöttek által a pálmakunyhóik részére kivágott pár fáról van szó. Az 1997-es Fertôzố (Contagious. Joe Napolitano, 1997) címú TV-filmben a kolera az isten háta mögött, láthatóan szegény emberek által halászott, majd a repüloón felszolgált, utána pedig egy amerikai rendezvényen is feltálalt ínyenc garnélarákkal kerül az Egyesült Államokba. Soderbergh Fertôzése nemcsak a film végén mutatja be az állati gazdatestektôl az emberekig vezetô utat - amit az egészségügy a filmben és a filmen kívül is a „kontaktok” felderítése során rekonstruálnak. Már a 
film elején is nagy hangsúly esik rá, ahogyan a zéró páciens némi köhögés közepette a „szabadon fogyasztható" (valójában a nagyobb folyadékfogyasztás érdekében kihelyezett) sós mogyoróban matat, majd átadja a bankkártyáját a pultosnak - mindezt a repülótéren, amely két kontinenst köt össze. A vírus, úgy tûnik, a tôkés profit útját követi, hiszen a zéró páciens azért utazott keresztül a világon, hogy kapcsolatokat építsen ki a cége számára, amely, emlékezzünk, kivágta azt a bizonyos fát, és otthontalanná tette a zoonózis forrásául szolgáló denevért.

Az 1979-es Alien (Ridley Scott), amely akkor került a mozikba, amikor Ronald Reagan világossá tette, hogy a jóléti intézmények fejlesztése helyett a szabadpiac kiterjesztésére kíván ráerôsíteni, akár a globális kapitalizmussal járó veszélyek figyelmeztetô tanmeséjeként is nézhetô. A címszereplô szörny úgy „fertôzi” meg az embereket, hogy még egy ismeretterjesztô weboldalon is vele példázzák a vírusok múködését (Woo 2016: 201). De csak a világúrbe kiterjesztett globális ipar és kereskedelem révén lesz képes a Föld lakosságát is fenyegetni, és a franchise-ban ezt a globális kereskedelmet egyre inkább egyetlen (nevében is nemzetköziségrôl árulkodó) cég, a WeylandYutani uralja, amely a profitszerzés érdekében attól sem riad vissza, hogy szándékosan próbáljon egy Alien példányra szert tenni, a lényben ugyanis csodálatos biotechnológiai lehetôségek rejlenek: „új gének, új vakcinák! A határ a csillagos ég!” (Alien: Resurrection. Jean-Pierre Jeunet, 1997). [14]

Az, hogy a Covid19 idején a levegó és a kanálisok egy pillanatra tisztábbá váltak, annak a következménye, hogy egy pillanatra leállt az a rendkívül környezetszennyezó gépezet, ami a kapitalizmust múködteti, ${ }^{[15]} \mathrm{s}$ amelynek pusztító potenciálja valójában abból ered, hogy a múködéshez folyamatosan növekednie kell, ami - mint ezt már a 70-es évek elején leszögezték a Római Klub híres jelentésében - egy véges bolygón nem kivitelezhetô. Az ökológiai ismeretterjesztố irodalomban egyre inkább bevett téma lett, hogy „nem térhetünk vissza a szokásos üzletmenethez" (Jackson 2009: 15, kiem: H.A.), mely fordulat most a járvány kapcsán új kontextusban jelentkezik: „A Covid19 pusztító és villámgyors globális hatása - a halottak, a megszokott életmód, a megélhetés elvesztése és a vállalkozások összeroppanása - mind azt demonstrálja, hogy milyen törékennyé és fenntarthatatlanná vált a modern világ. Ha ebból a krízisből erôsebben és ellenállóbban akarunk kilépni, nem térhetünk vissza a »szokásos üzletmenethez«. Új »normálisra« lesz szükségünk. Olyanra, amely nem ismétli meg az olyan jól ismert hibákat, mint a fenntarthatatlan termelés, a környezeti pusztítás és az egyre növekvô egyenlôtlenség” (Mazzucato 2020).

A járvány alatt burjánzásba kezdô immunológai metaforák vonzását követve Kevin McKenna, a skót The National újságírója már áprilisban úgy fogalmazott, hogy „a koronavírus által okozott problémák egy még sokkal komolyabb vírus - a kapitalizmus - fertózése révén váltak gyulladássá”, majd ki is fejti a metaforát. Eszerint

a fertôzố kapitalizmus számos ponton hasonlít a vírusokhoz. Egy olyan törzsbe tartozik, amely hosszú ideig nem okoz tüneteket az embereknél, mígnem a fertôzés hirtelen válik nagyon kellemetlenné. A kiegyensúlyozott környezetben, amikor nem hiányoznak 
alapvetô szükségletek, mint a víz, az élelem, a lakhatás, a ruházkodás és az értelmes

munka, gyakran észrevehetetlen. De amint az emberek észrevehetố hiányt szenvednek ezekben, a kapitalizmus virulenssé válhat. (McKenna 2020)

Brendan Montague, a The Ecologist publicistája júniusban még sokkal alaposabban megmagyarázza, miért is olyan alkalmas a vírusmetafora a helyzet ökopolitikai megvilágítására. Eszerint
A kapitalizmus úgy fertózi meg a gazdatestet, mint egy vírus, úgy változtatva meg annak a viselkedését, hogy a gazdatest energiája innentôl a vírust tartsa életben és az exponenciálisan szaporodhasson. (...) Az emberre patogén vírusokhoz hasonlóan a tôke kimeríti a gazdatestet és túlterheli azt: mind az egyéni munkást, mind pedig a politikai szervezetet megbetegíti, sôt, akár meg is ölheti.

Bár az érvelés gyakran azt sugallja, hogy a Covid19 csak ráerôsített a kapitalizmus említett hatásaira, olykor úgy túnik, hogy a mém „és a vírus a vakcina” tagmondata ennél a némileg átalakított verziónál is múködik. Legalábbis olyankor, amikor azt olvashatjuk, hogy a vírus „kiemelte” a nyugati berendezkedés sajátosságaiból adódó problémákat, „leleplezte” a hiányosságokat - amelyek a „szokásos üzletmenet” folyamán eleddig nem tûntek fel. A World Economy Forumon például ezt olvashatjuk:

a halálos vírus rámutatott a nyugati kapitalista gazdaságok néhány gyenge pontjára. Most, hogy a kormányok harcba léptek, most van lehetôség, hogy javítsunk a rendszeren. Ha nem ezt tesszük, nem lesz esélyünk a harmadik legfôbb krízissel szemben - ami nem más, mint a bolygó fokozódó lakhatatlansága -, ahogyan a jövốben még elôttünk álló kisebb krízisekkel sem (Mazzucato 2020).

A koronavírus eszerint azt tette a társadalom „szervezetével”, amit a vakcinák általában tesznek a biológiai szervezettel: „felhívják” az immunrendszer figyelmét a kór-okozóra, aminek következtében antitestek kezdenek termelôdni. Ez esetben, a fentiek alapján ezek a részvételi demokrácia és a jóléti állam azon sejtjei volnának, amelyek a nagyvállalatok hasznának egy (vagy nagy) részét a teljes közösség javára fordítanák, és egyszersmind meggátolnák azt is, hogy a gazdasági és politikai intézkedések a rövid távú haszon érdekében hosszú távon károsítsák azokat a rendszereket, amelyek lehetôvé teszik ennek a közösségnek a (jól)létét. „Nyájimmunitásra van szükségünk”, írja Montague, amit a következôképp részletez: „az állami egészségügyi szervek, az idôsotthonok, a beteggondozók, a buszvezetôk, az iskolai tanárok és mindazok, akik hasznos munkát végeznek: ôk a mi antitesteink".

\section{A zombifilm mint szolidaritásvakcina}

Mint már volt róla szó, a kulturális képzeletben a „zombifertôzés” a marginalizált rétegek 
növekedését és e tömeg fenyegetését is felidézheti, miközben a fertôzés elkerülése a szó szoros értelmében „harc a túlélésért”. Nem azt sugallja ez, hogy az „ember” ezekben a filmekben éppen a racionális, önálló és önérdekú homo oeconomicus megtestesítóje (Woo 200)? Vajon ekképp a megmaradó csoportok hadakozásának és különösen egyeseknek a mások alávetésére tett próbálkozása nem a McKenna által „kapitalovírusnak” nevezett kórokozó garázdálkodását érzékelteti?

A ma leginkább divatos zombisorozatok általában egy járványügyi apokalipszis után játszódnak, és a kezdô epizódok mindannyiszor a közösség szétesésérôl és a megszokott nyugati életforma hirtelen megszúnésérôl szólnak (Bishop 2009: 17-24.). Ám miután túljutunk a veszély természetének és a vele szemben való védekezés lehetôségeinek a megismerésén, a sorozatok fókusza egyre inkább átkerül az „egészségesek” [16] egymáshoz való viszonyára, amelynek ábrázolása néhol alig különbözik egy kortárs társadalmi drámától. Másrészrôl viszont az önzés és a segítôkészség problematikáját tekintve az újabb zombisorozatok és a járványfilmek között számos párhuzam van, amelyek mindannyiszor a „szociális távolságtartást” ha nem is ellenpontozó, de mindenképp ellensúlyozó közösségi összefogásra teszik a hangsúlyt - ami a posztapokaliptikus zombifilmben kifejezetten egy rendszerszintû́ társadalmi revízió fontosságát hangsúlyozza. „Újraépítjük a világot” - ez lesz a Walking Dead 9. évadának egyik visszatérô jelmondata.

Bár a közösségépítés lassan megkezdődik, a sorozatban fordulópontot jelent, amikor a fôszereplő fia, akit mindenki szeret, megfertóződik, és halála elôtt azt kéri a „felnôttektôl”, hogy ne egymással háborúzzanak a megmaradt erôforrások kisajátításáért, hanem fogjanak össze. Ez a krisztusi figura a maga szeretetparancsolatával, amely aztán szinte evangéliumszerúen terjed a közösségek között, látszólag csak egy már elhasznált narratív klisét alkalmaz. De úgy is felfoghatjuk, hogy ezt a klisét használja fel, hogy a kultúránk jelenleg is uralkodó nagy történetét megkérdójelezze, amely szerint az „erôsebb gyôz”, és egyedül az önérdek és az önmagunkkal való törôdés a kifizetődô, ami egy posztapokaliptikus világban különösen helyénvalónak tûnhet. Ami egybehangzik a járványfilmek azon hajlandóságával, hogy a másikról való gondoskodást akkor is erényként állítsák be, ha az ésszerúség a távolságtartás és a kívülállás mellett szól. A posztapokaliptikus zombisorozatnak ezen túlmenően arra is van ideje és elég szereplöje, hogy - egyfajta szimulációként - az említett viselkedésformák hosszú távú logikus kifutását és a társadalom egészét illetô következményeit is érzékeltessék.

„Már nem csak a puszta túlélés reményében küzdünk, hanem egy új kezdetet teremtünk meg” (9:2) - hangzik el a Walking Dead 9. évadjának elején. Hogy a Walking Deadben mit jelent a „puszta túlélés”, és miért gond, amikor ez a koncepció rendszerformáló erôvé válik, azt jól érzékelteti egy alternatív „társadalmi lét” kibontakozása is, a Suttogóké, akiknek a vezetôje, Alpha úgy véli, hogy az „irracionális” kötôdések csak gyengeséghez vezetnek, és „, legerôsebb akkor vagy, amikor a saját véreddel végzel" (10: 2). Ez a természetközeliként beállított (az elôbbi esetben az oroszlán viselkedéséhez hasonlított), ám valójában a „puszta élettel” való megelégedést hirdetô társulás, amelyet Alpha „természetes kiválasztódásnak” nevez (9: 11). Alpha lánya éppen azért hagyja ott anyját és „falkáját” a konvencionálisabb közösségek kedvéért, mert az utóbbiak „törôdnek 
egymással és velem is törôdnek” (9: 15). Az „erôsebb gyôz” reduktív ideológiáját érdekesen ellenpontozza egy másik szereplô evolúciós eszmefuttatása, aki a következố rövid történeti víziót vázolja fel a civilizáció hajdani kezdeteirôl; eszerint az ôsemberek

körbeülték a tábortüzet, zene és képek formájában megosztották történeteiket egymással és közös identitást teremtettek meg. Utána meg közösségek alakultak és gyarapodtak. (...) Szóval ez az, ami megkülönböztet minket az állatoktól, és ami összehoz minket. A legerôsebb győz? Megosztunk ezt-azt... részben ez tesz minket erôssé. (Walking Dead 9:7)

Valóban, a sorozatban szinte a szemünk elôtt játszódik le, illetve játszódik újra a társadalmi evolúció azon folyamata, melynek során a mások iránti bizalmatlanság és a mások veszteségébôl nyereséget kovácsoló társadalmi formációk kudarcot vallanak, míg a bizalomra és a segítségre épülốk fennmaradnak. És bár az egyedek közti vetélkedés és a túlélés elsôdlegességének a törvénye igen jól magyarázhatja a betegektôl való távolságtartást a járványfilmekben és különösen a szörnyfilmekben, Darwin valójában nem csak azt hangsúlyozta, hogy „a magas erkölcsi színvonal az egyes embernek és gyermekeinek csak igen csekély, vagy semmi elönyt nem nyújt a törzs többi tagjával szemben”, hanem ugyanitt azt is, hogy „a jó tulajdonságokkal felruházott emberek elszaporodása és a törzs általános erkölcsi színvonalának emelkedése óriási elônyt nyújt az egész törzsnek más törzsekkel szemben.” (Darwin 1961: 185)

Talán nem véletlen, hogy éppen a járványhelyzettel foglalkozó realisztikus filmek és az összeomlás után játszódó szörnyfilmek azok, amelyek egyszerre domborítják ki az önzetlen viselkedés veszélyességét (és ennélfogva látszólagos értelmetlenségét) és dicsérik annak erényét is. Hiába olyan értelmetlen ugyanis, funkciója van: a „reciprok altruizmus” gyakorlatának kifejlődése Gintis kutatócsoportja szerint éppen olyan körülmények között valószínúsíthetô, „amikor a csoportot kihalás vagy szétesés fenyegeti, például háború, betegség vagy éhínség következtében, amikor tehát a kooperáció a leginkább fontos a túlélés szempontjából." (Gintis et. al. 2003: 163)

A járványfilmek Szent Grálja általában az ellenszer megtalálása, aminek a reménye a posztapokaliptikus zombifilmben általában már korán elhal. A fentieket meggondolva azonban mégiscsak gyógyulásról: a politikai test gyógyulásának bemutatásáról van szó. A zombikkal, majd a „szörnyetegként” viselkedô emberek hatalmaskodásával szemben ellenálló sejtek alakulnak ki csoportok, amelyeknek a tagjai a másokról való gondoskodást nem gondolják az önfenntartással összeegyeztethetetlenek. A társadalmiság középponti eszméjeként az independencia interdependenciává íródik át, a „harcosok” megvédik az arra képteleneket, a csoportok pedig gazdasági közösségként is önfenntartók (vagy legalábbis kifejezetten ez a legföbb törekvésük). Az egyik közösség egy olyan hipermodern telepen alakul ki, amelyet még a járvány elôtt éppen a zöld átállás jegyében alakítottak ki napelemekkel, zárt és ciklikus energiaellátással, törpe vízerômunvel, ellenálló gabonafajták termesztésével. Egy másik közösség vezetôje saját bevallása szerint is azért alkalmas a tisztjére, mert egy hagyományos „farmon nôtt fel”. A termeléshez szükséges eszközöket a 18. század eszközeit leíró könyv alapján állítják össze - és látogatást tesznek egy múzeumban is, ahol kenukat, genetikailag tiszta ôsvetômagokat és egy szekeret 
zsákmányolnak. Akár azt is mondhatnánk, hogy a Walking Dead elóbb egy 21. századi ökofalu, majd a környezố túlélốk összes csoportját összefogni kívánó „szolidáris gazdaság” megszervezésével szegül szembe a modern világot sújtó archetipikus járvánnyal, és voltaképpen a gazdasági rendszer újraszervezésével kapcsolatos vitákba bocsátkozik bele, amikor „a felhalmozás (...) válsághoz vezetô rendszerével szemben egy másik, a társadalmi és ökológiai rendszerek fenntarthatóságát szolgáló, demokratikus gazdasági modellt javasol” (Gagyi 2020: 7).

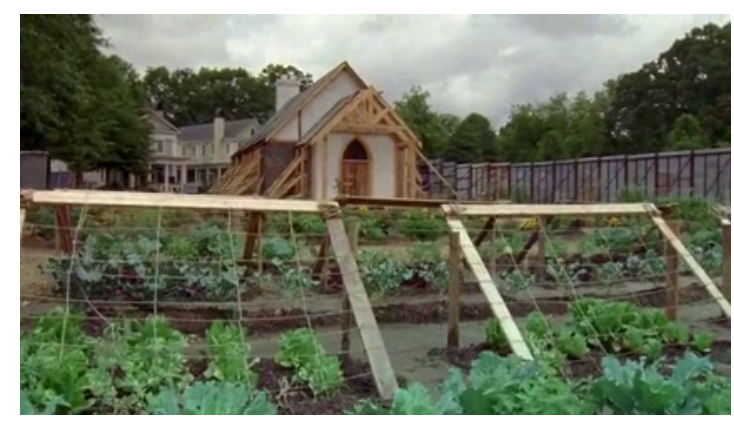

A The Walking Dead 9. évadja Alexandria, a túlélók egyik otthonává váló ökogazdasági létesítmény képével kezdődik (TV-sorozat. Frank Darabont, Angela Kang, 2010-).

A Walking Deadben a zombijárvány eszerint nem a betegség, hanem inkább a „vakcina” - hiszen ez az a hatás, amely ellenállásra készteti és a „kapitalovírus” elpusztítására készteti a járványt túléló közösség „immunrendszerét”. Mint Montague a média által népszerúsített egészségügyi nyelvezetet tréfásan imitálva írja: „A kutatások arra utalnak, hogy a közösségi tulajdon csírájában pusztítja el a kapitalovírust”. A sorozat már jó pár éve egy olyan társadalmi újraszervezôdésben láttatja tehát a teljes társadalmi-gazdasági összeomlás ellenszerét, amely 2020 valóságában a Covid 19 kapcsán vált hirtelen elképzelhetô lehetôséggé. Hiszen még a nem kifejezetten baloldali érzelmú publicisták is arra a megállapításra jutottak, hogy „az egészséges gazdaság jövôje nem a nagyvállalatokban, hanem a kisvállalkozókban testesül meg, akik nem akarnak sokat, csak egy kis esélyt és kiegyenlített játékteret" (Lane 2020). Lehet, hogy a koronavírust sem azért kellene „vakcinának” tekinteni a bolygó „betegségére”, mert csökkenti az emberi populációt, hanem azért, mert ellenállóbbá teheti azt.

A Walking Dead persze csak egy sorozat a sok közül, a média mémjei és az internetes publikációk pedig csak vélemények. De ha a vélemény lehet virális, akkor a vakcina is lehet egy-egy gondolat. Nem minden vakcina jár passzív immunizációval, nem mindegyik „kész” ellenanyagot, azaz már meglevô megoldást szállít. Az aktív immunizáció során a szervezetbe elölt vagy legyengített kórokozókat juttatnak, amelyek immunválaszt serkentenek - mintegy kiprovokálva, hogy a test „kiálljon” magáért. Ha a Covid19 valóban arra serkenti a világ kormányait, hogy tegyenek erőfeszítéseket a még elốttünk álló krízisek enyhítésére, akkor a Covid19 a bolygó immunizálásában leginkább egy ilyen, a „legyengített” kórokozó szerepét játszhatná. Emellett persze az „elölt”, vagyis az immunrendszer számára igazinak látszó, ám valójában veszélytelen kórokozó bejuttatása is hozzájárulhat a sikerhez. Márpedig a neurológusok szerint a film pontosan 
így múködik: igazinak látszik, pedig valójában nem az, megijedünk tóle, de nem futunk el. Evolúciós pszichológusok szerint ilyenkor fejben gyakoroljuk a menekülést (Tooby-Cosmides 2001: 21). Vajon lehet-e a posztapokaliptikus járványfilm a társadalom immunrendszerének a képzeletbeli tréningje? Alakíthat-e ki a szörnyfilmekben felépülő bajtársiasság képzete ellenállást a neoliberális verseny csábításával szemben? Lehet a zombifilm vakcina?

\section{Jegyzetek}

1. Lovelock a hipotézist a 70-es években számos cikkben alapozta meg, a koncepciót a nagyközönség körében azonban az 1979-es könyv, a Gaia: A new look at life on Earth (Oxford, Oxford University Press) tette népszerūvé.

2. Az egyként 1995-ös Járvány és a Vírus mellett ilyen a Halálzóna minisorozat is (The Hot Zone. James V. Hart, Brian Peterson, Kelly Souders), amely ugyan 24 évvel késôbb, 2019-ben készült, Richard Prestonnak a film alapjául szolgáló regénye - amely egyébként a Virus esetében is a legfóbb inspirációként szolgált a film készítôi számára - 1987-ben íródott, valós események alapján. Az Egyesült Államokbeli Reston katonai bázis legénységének az Ebola egy alfajával kellett megbirkóznia - amely szintén majmokról terjedt az emberre (bár, mint kiderült, ez az alfaj a homo sapiensre nem különösebben ártalmas).

3. Lásd https://www.rainforestfund.org/who-we-are/

4. Ilyen a himlô, a bárányhimlố vagy a tuberkolózis, amely a szarvasmarhákról került az emberekre, vagy az influenza, vagy a szamárköhögés, ami a disznókról. A járványveszély a mezőgazdasági termelés és a technológiai fejlődéssel „összezsugorodó” világ velejárója (Wald 4-6.).

5. A 2008-as kétrészes $A z$ Androméda-törzsben a címszereplô kórokozóról nem csak az derül ki, hogy mesterségesen készítették, hanem az is, hogy a jövốből küldték vissza azért, hogy ezzel rávilágítsanak arra, milyen törékeny az élet, és milyen értékesek lehetnek azok az ember számára „haszontalannak” tartott életformák is, mint az az Infernus baktérium, amely a történet idején már veszélyeztetett faj, de amely az egyedüli ellensége lehet a végzetes Andromédának.

6. A megszokás mellett ezt nem nehéz az amerikai politika neoliberális irányultságával is összefüggésbe hozni, aminek a kezdetét többek közt az jelezte, hogy Reagan leszereltette a Fehér Ház tetejérôl azokat a napelemeket, amelyeket még Carter szereltetett fel, mondván, hogy a globális szabadpiaci nyitástól várt gazdasági fellendülés majd az ökológiai problémákat is megoldja.

7. Errổl Malthus 19. századi munkásságán túl a 70-es évek „ökológiai ébredését” elôiidézô és széles körben ismertté vált tudományos irodalom gondoskodott - mint az 1972-es $A$ növekedés határai címú, az ökológiában mérdföldkônek számító jelentés és számos tudományos bestseller, vagy a Population Bomb (1968) Paul Erlich tollából, amelyet a hasonlóan sokatmondó címú Ecoscience: Population, Resources, Environment (1977) követett.

8. Ruth Mayer szerint nem elsốsorban 9/11 a meghatározó a bioterrorizmus témájának a megjelenésében, hanem inkább az, hogy „egy globális világrendben a »külsô̋ és a »belsôß közti különbség elbizonytalanodik” (Mayer 9), ami egyszerre kedvez az ellenséget „belülre” helyezô vírustematikának és a „belülrôl bomlasztó” elemektôl - bevándorlótól, csempészektôl, ügynököktôl és forradalmároktól - való félelem megjelenítésének, ami már a hidegháborús vírusfilmekre is jellemző. Ezt a koncepciót támogatja, hogy a globális világrend kialakulásakor - de még 9/11 elôtt - hirtelen számos bioterrorizmus témájú film készült - mint például a Delta Force kommandó (Operation Delta Force. Sam Firstenberg, 1997), a Repüló eröd (Deadly Outbreak. Rick Avery, 1995), a D.R.E.A.M. Team (Dean Hamilton, 1999) vagy a Mission Impossible II (Brian De Palma, 2000). 
9. Ebben a 2015-ös narratívában leginkább a vírus „pozitív”, vagy legalábbis elsô pillantásra pozitívnak gondolt élettani hatása az újszerú, ami azután a 2018-as dán Gyilkos esô (The Rain. Kenneth Kainz, Natasha Arthy) és a 2019-es $A$ szabadulás (The Passage. Liz Heldens) és a $V$-Wars - Vérháború (Brad Turner, Ted Adams) sorozatok narratíváját is meghatározta - számos konvencióbontónak szánt 21. századi zombifilmé mellett.

10. A harmadik világ népességével kapcsolatos ökológiai vitát illetôen lásd Hódosy 2019.

11. Michael Richardson szerint „A zombikról szóló euro-amerikai diszkurzus hajlamos arra fókuszálni, hogy vajon a zombi jelenség igaz-e, hogy vajon ezek a lények valóban a sírból jöttek-e vissza. Pedig bizonyos értelemben ez irreleváns: a zombi valós, mert a rabszolgaság megszemélyesítéseként kitartó jelenléttel bír a történelmi emlékezetben" (123-124.).

12. Mint Victoria Carrington bemutatja, az Egyesült Államokban egyre gyakrabban rendeznek olyan tüntetéseket, amelynek a résztvevôi zombinak öltöznek: „Ezek a menetek gyakran a polgárok azon érzéséhez kapcsolódtak, hogy a gazdasági összeomlás után a neoliberális kormányok keveset tettek a megsegítésük érdekében. A lelketlen kormányok által cserbenhagyott, tehetetlen polgárok és a hagyományos identitásformák ellehetetlenülése - ezek voltak azok a témák, amelyek ezekkel a menetekkel asszociálódtak, amelyek legalább annyira voltak politikai megnyilvánulások, mint szórakoztató tömegrendezvények (25).

13. Robert Kochnak a bakterológia - különösen a tuberkolózis és a kolera - terén végzett úttörô kutatásai az 1880-as években folytak, amiért 1905-ben kapott Nobel díjat, a vírust pedig elôször 1892-ben azonosította egy Dmitrij Ivanovszkij nevú tudós.

14. Mindebból akár úgy is túnhet (már ha valaki nem látta a filmeket), hogy a globális kapitalizmusnak a technológiai fejlesztések iránti preferenciája legalább a vakcina elôteremtésében hasznos lehet. A Covid19 kapcsán azonban ezzel éppen ellentétes híreket lehetett olvasni. Eszerint, bár egy új vírus megjelenése aligha volt meglepő az egyre-másra felbukkanó madárinfluenza, sertésinfluenza és egyéb járványok óta, mégsem dolgoztak ki ellenük olyan vakcinát, amely a Covid19 elleni szer piacra dobását felgyorsíthatta volna. Miért? „Mert a négy cég, amely a szérumok gyártását uralja - a Pfizer, a Merck, a GlaxoSmithKline [GSK] és a Sanofi - nem látott elég potenciális hasznot a koronavírusok elleni harcban, ezek ugyanis úgy tûnik, néhány év után eltûnnek, s helyettük inkább olyan vírusokkal foglalkoztak, amelyek kitartóbbak" (Sweeney 2020).

15. Mint láttuk, a zoonózis már említett jelensége alapvetôen a profitorientált ipari termeléshez vezethetô vissza, ezen belül is elsôsorban a monokultúrákat létrehozó és intenzíven múvelt növénytermesztésnek köszönhetô, amely sarokba szorítja a vadvilágot, és így kaput nyit a vírusok elôtt az állatokról az emberre való átugráshoz. A termőföldeket talajerózióval és elsivatagosodással fenyegeti, kimeríti az édesvízkészleteket, a növényeket a kelleténél fogékonyabbá teszi a betegségekre, a múvelés során felhasznált olajszármazékok felhasználásával elképesztô mennyiségú széndioxidot juttat a levegóbe, amelyet az erdôktôl elvett területeken termesztett takarmánnyal táplált tenyészállatok által kiböfögött metán egészít ki üveghatású gáz gyanánt. Az ipar és a kereskedelem által felhasznált erôforrások és a közben felhasznált energia, amely a termelés globálissá válásával egyre csak nô és szintén széndioxidtermeléssel jár, csak ezután jön.

16. A Walking Deadben ez a meghatározás technikailag nem áll, mivel kiderül, hogy már mindenki fertôzött, a betegség/zombiság azonban a látenciából csak akkor válik tényleges betegséggé, ha a beteg meghal (amikor is a teste vegetatív módon múködik tovább). A zombivá válás ekként tehát a betegség utolsó „stádiuma” (ahogyan az AIDS a HIV-fertôzés végsô klinikai stádiuma). 


\section{Irodalomjegyzék}

- Attfield, Robin (1999): The Ethics of the Global Environment. Edinburgh University Press.

- Benedek Zsófia (2014): A rövid ellátási láncok környezeti hatásai. In Magyar Tudomány 8, 993999.

- Bhushan, Chandra (2020): Relation between coronavirus and global warming: Climate crisis changes disease pandemics. Financial Express, 02. 28. URL:

https://www.financialexpress.com/opinion/relation-between-coronavirus-and-globalwarming-climate-crisis-changes-disease-pandemics/1883450/Bishop, Kyle (2009): Dead Man Still Walking: Explaining the Zombie Renaissance. Journal of Popular Film \& Television, 37.1, $16-25$.

https://doi.org/10.3200/JPFT.37.1.16-25

- Bishop, Kyle William (2010): American Zombie Gothic. The Rise and Fall (and Rise) of the Walking Dead in Popular Culture. Jefferson and London, McFarland.

- Bosselman, Andy (2019): Greta Thunberg in Denver: "The Older Generations Are Failing Us." Streetsblog Denver, 10. 11. URL: https://denver.streetsblog.org/2019/10/11/greta-thunberg-indenver-the-older-generations-are-failing-us/

- Braidotti, Rosi (2018): A poszthumántudományok felé. Ford. Lovász Ádám. Helikon 4, 435-451.

- Brown, Jennifer (2013): Cannibalism in Literature and Film. London, Palgrave Macmillan. https://doi.org/10.1057/9781137292124

- Carrington, Victoria (2016): The 'Next People': And the Zombies Shall Inherit the Earth. In Carrington, Victoria - Rowsell, Jennifer - Priyadharshini, Esther - Westrup, Rebecca (szerk.): Generation Z. Zombies, Popular Culture and Educating Youth. Norwich, Spinger, 21-36. https://doi.org/10.1007/978-981-287-934-9_3

- Carson, Rachel (2007): Néma tavasz. Ford. Makovecz Benjamin. Páty, Katalizátor Iroda.

- Chatalos, Peter (2012): Gaia living with AIDS: towards reconnecting humanity with ecosystem autopoiesis using metaphors of the immune system. In Rust, Mary-Jayne és Totton, Nick (szerk.): Vital Signs. Psychological Responses to Ecological Crisis. London, Karnac, 33-45.

- Crichton, Michael (1993): Az androméda törzs. Ford. Bars Sándor. Budapest, JLX Kiadó.

- Dahlman, Carl J. (2012): The World Under Pressure: How China and India Are Influencing the Global Economy and Environment. Stanford, Stanford University Press. https://doi.org/10.11126/stanford/9780804777131.001.0001

- Darwin, Charles (1961): Az ember származása. Ford. Katona Katalin. Gondolat.

- Diamond, Jared (2000): Háborúk, járványok, technikák. Ford. Födô Sándor. Budapest, Typotex Kiadó.

- Dobos Emese (2020): Meglennénk, ha minden külföldi élelmiszer eltúnne a polcokról? HVG, 05. 28. URL:

https://hvg.hu/gazdasag/20200428_Megvalosithato_hogy_mindenki_helyi_elelmiszert_fogyasszon

- Domschitz Mátyás (2020): Ha nem zsákmányolnánk ki a természetet, ez a járvány sem lenne. Index, 04.02. URL: https://index.hu/gazdasag/2020/04/02/kina_vadallat_piac_koronavirus_mezogazdasag_vuhan_denever_tobz 2Oo7nZbDq9t6McOGBuT6ACn-mQmE7V3QJKEejNEPlv30dVkRxT0

- Este, Jonathan (2020): Migration: how Europe is using coronavirus to reinforce its hostile 
environment in the Mediterranean. The Conversation, 05. 13. URL:

https://theconversation.com/migration-how-europe-is-using-coronavirus-to-reinforce-itshostile-environment-in-the-mediterranean-137840

- Foresti, Marta (2020): Less gratitude, please. How COVID-19 reveals the need for migration reform. Brookings, 05. 22. URL: https://www.brookings.edu/blog/future-

development/2020/05/22/less-gratitude-please-how-covid-19-reveals-the-need-formigration-reform/

- Foster, John Bellamy (1999): Vulnerable Planet. A Short Economic History of the Environment. New York, Monthly Review Press.

- Gagyi Ágnes (2020): Szolidáris gazdaság és kapitalizmus. Fordulat, 27: 5-35.

- Gintis, Herbert, Bowles, Samuel, Boyd, Robert és Fehrd, Ernst (2003): Explaining altruistic behavior in humans. Evolution and Human Behavior, 24: 153-172.

https://doi.org/10.1016/S1090-5138(02)00157-5

- Gonçalves, André (2019): Supply Chains Cause 90\% Of Companies' Environmental Impacts. How Can They Be Improved? Youmatter, 03. 19. URL:

https://youmatter.world/en/sustainability-supply-chain-27935/

- Greer, John Michael (2013): Not the Future We Ordered. Peak Oil, Psychology, and the Myth of Progress. Karnac Books.

- Hardin, Garret (2005): A mentốcsónak erkölcstana. Ford. Könczöl Miklós és Mihályi Gabriella. In Környezeti etika. Szöveggyújtemény. Szerk. Lányi András és Jávor Benedek. Budapest, L'Harmattan.

- Hoberman, James (2003): The Dream Life. Movies, Media and the Mythology of the Sixties. New York \& London, The New Press.

- Hódosy Annamária: Szuperhôsfilm az antropocénben, avagy az MCU ökopolitikája. Apertúra, 2019. ôsz. URL: https://www.apertura.hu/2019/osz/hodosy-szuperhosfilm-az-antropocenbenavagy-az-mcu-okopolitikaja/

https://doi.org/10.31176/apertura.2019.15.1.7

- Hoffower, Hillary (2020): A certain horrible subset of the internet is calling the coronavirus 'boomer remover'. Business Insider, 03. 23. URL: https://www.businessinsider.com/millennialsgen-z-calling-coronavirus-boomer-remover-reddit-2020-3

- Jackson, Tim (2009): Prosperity without Growth. Economics for a Finite Planet. London, Earthscan. https://doi.org/10.4324/9781849774338

- Jamieson, Dale (2008): Ethics and the Environment. An Introduction. Cambridge, Cambridge University Press.

- Johnson, Jennifer (2020): We are not the virus. Verso, 03. 27. URL: https://www.versobooks.com/blogs/4622-we-are-not-the-virus

- Joyce, Kathryn (2020): The Long, Strange History of Bill Gates Population Control Conspiracy Theories. How the billionaire philanthropist displaced George Soros as the chief bogeyman of the right. Typinvestigations, 05. 12. URL:

https://www.typeinvestigations.org/investigation/2020/05/12/the-long-strange-history-ofbill-gates-population-control-conspiracy-theories

- Kovács József (2008): Környezeti etika. Világosság, XLIX. 9-10, 75-107. 
- Lambermont, Paige (2020): Coronavirus Is Making Ecofascists Say the Quiet Part Out Loud. Instituteforenergyresearch, 05 17. URL: https://www.instituteforenergyresearch.org/climatechange/coronavirus-is-making-ecofascists-say-the-quiet-part-out-loud/

- Lane, Randall (2020): Greater Capitalism. How the Pandemic is Permanently Reshaping our System for the Better. Forbes, 05. 26. URL:

https://www.forbes.com/sites/randalllane/2020/05/26/greater-capitalism-how-the-pandemicis-permanently-reshaping-our-economic-system-for-the-better/\#le5339a871cl

- Lányi András (2013): Morális klímaváltozás. Iskolakultúra, 12: 40-48.

- Lovelock, James (2007): The Revenge of Gaia: Earth's Climate Crisis and the Fate of Humanity. New York, Basic Books.

- Lynch, Patrick (1995): Carriers. New York, Villard.

- Malm, Andreas (2019): Forradalmi stratégia egy felmelegedô világban. Tanulságok az orosztól a szíriai forradalomig. Fordulat, 25: 192-217.

- Mayer, Ruth (2007): Virus Discourse: The Rhetoric of Threat and Terrorism in the Biothriller. Cultural Critique, 66.2, 1-20. https://doi.org/10.1353/cul.2007.0019

- Mazzucato, Mariana (2020): Coronavirus and capitalism: How will the virus change the way the world works? World Economic Forum, 04. 02. URL:

https://www.weforum.org/agenda/2020/04/coronavirus-covid19-business-economics-societyeconomics-change

- McKenna, Kevin (2020): We'll never have a vaccine to cure contagion of deadly capitalism. The National, 04. 15. URL: https://www.thenational.scot/news/18379478.never-vaccine-curecontagion-deadly-capitalism/

- Montague, Brendan (2020): Capitalism is the virus. The Ecologist, 06. 13. URL: https://theecologist.org/2020/jun/13/capitalism-virus

- Moore, Jason W. (2019): Az olcsó természet vége, avagy rájöttem, hogy nem kell félteni „a” természetet, meg is lehet szeretni a kapitalizmus válságát. Ford. Tillmann Ármin. Fordulat, 25: $17-54$.

- Murphy, Bernice (2011): Imitations of Life: Zombies and the Suburban Gothic. In Christie, Deborah - Lauro, Sarah Juliet (szerk): Better Off Dead. The Evolution of the Zombie as Post-Human. NewYork, Nordham University Press, 116-138. https://doi.org/10.5422/fordham/9780823234462.003.0009

- Ostherr, Kirsten (2005): Cinematic Prophylaxis. Globalization and Contagion in the Discourse of World Health. Duke University Press.

- Pianigiani, Gaia - Bubola, Emma (2020): As Coronavirus Reappears in Italy, Migrants Become a Target for Politicians. The New York Times, 08. 28. URL: https://www.nytimes.com/2020/08/28/world/europe/coronavirus-italy-migrants.html

- Preston, Richard (1995): Halálzóna. Ebola: a gyilkos vírus. Ford. Hamvai Kornél. Budapest, Európa Kiadó.

- Richardson, Michael (2010): Otherness in Hollywood Cinema. New York, Continuum. https://doi.org/10.5040/9781628928839

- Sartin, Jeffrey S. (2019): Contagious Horror: Infectious Themes in Fiction and Film. Clinical Medicine $\Xi$ Research, 17: 1-2. 41-46.

https://doi.org/10.3121/cmr.2019.1432 
- Schwab, Klaus (2020): Now is the time for a 'great reset'. World Economic Forum, 06. 03. URL: https://www.weforum.org/agenda/2020/06/now-is-the-time-for-a-great-reset/

- Shiva, Vandana (1991): The Violence of the Green Revolution. Third World Agriculture, Ecology and Politics. London, Zed Books.

- Stevenson, Robert Louis (1978): „Dr. Jekyll és Mr. Hyde különös esete.” Ford. Benedek Marcell. In Titokzatos Idegen. Négy klasszikus angol kisregény. Budapest, Európa.

- Stoker, Bram: Drakula. Ford. Sóvágó Katalin. Budapest, Európa Kiadó, 2006.

- Sweeney, Neal (2020): How capitalism and racism hold back a COVID-19 cure. Liberation, 05. 07. URL: https://www.liberationnews.org/how-capitalism-and-racism-hold-back-a-Covid-19cure/

- Takács-Sánta András (2004): „Velünk kísérleteznek.” In Horgas Judit (szerk.): Ligetszépe. Ökológiai Olvasókönyv. Budapest, Liget Múhely Alapítvány.

- Tenbarge, Kat (2020): Gen Z sparked backlash by calling coronavirus the 'boomer remover,' but actual teens say it's not a serious trend. Insider, 03. 26. URL: https://www.insider.com/genz-boomer-remover-coronavirus-teen-vanessa-hudgens-toilet-seat-2020-3

- Tooby, John - Cosmides, Leda (2001): Does Beauty Build Adapted Minds? Toward an Evolutionary Theory of Aesthetics, Fiction and the Arts. SubStance, 94/95: 6-27. https://doi.org/10.1353/sub.2001.0017 https://doi.org/10.2307/3685502

- Wald, Priscilla (2007): Contagious. Durham, Duke University Press.

- Woo, Yunjin La-mei (2016): Infecting Humanness: A Critique of the Autonomous Self in Contagion. In Nixon, Kari and Servitje, Lorenzo (szerk.): Endemic. Essays in Contagion Theory. London, Palgrave Macmillan, 191-217. https://doi.org/10.1057/978-1-137-52141-5_9

\section{Filmográfia}

- 12 majom (12 Monkeys. Terry Gilliam, 1995)

- 28 héttel késôbb (28 Weeks Later. Juan Carlos Fresnadillo, 2007)

- A szabadulás (The Passage. Liz Heldens, 2019)

- Alien 1. A nyolcadik utas: a Halál (Alien. Ridley Scott, 1979)

- Alien 4) Feltámad a halál (Alien: Resurrection. Jean-Pierre Jeunet, 1997)

- Alkonytájt (Near Dark. Kathryn Bigelow, 1987)

- Az Androméda-törzs (The Andromeda Strain. Robert Wise, 1971)

- Az Androméda-törzs (The Andromeda Strain. TV minisorozat. Mikael Salomon, 2008)

- Az élóhalottak éjszakája (Night of the Living Dead. George A. Romero, 1968)

- Contagious (TV-film. Joe Napolitano, 1997)

- Csillagok közt (Interstellar. Christopher Nolan, 2014)

- D.R.E.A.M. Team (Dean Hamilton, 1999)

- Elveszett fiúk (The Lost Boys. Joel Schumacher, 1987)

- Fertózés (Contagion. Steven Soderbergh 2011)

- Godzilla II - A szörnyek királya (Godzilla: King of the Monsters. Michael Dougharty 2019)

- Gyilkos esố (The Rain. TV-sorozat Kenneth Kainz, Natasha Arthy, 2018-2020) 
- Halálzóna (The Hot Zone. TV-sorozat. James V. Hart, Brian Peterson, Kelly Souders, 2019.)

- Hamburgi betegség (Die Hamburger Krankheit. Peter Fleischmann, 1979)

- Helix (TV-sorozat. Ronald D. Moore, Lynda Obst, Steven Maeda, Brad Turner. 2014-15.)

- Hell of the Living Dead (Bruno Mattei, Claudio Fragasso, 1980)

- Inferno (Ron Howard, 2016)

- Járvány (Virus. Armand Mastroianni, 1995)

- Kingsman: A titkos szolgálat (Kingsman: The Secret Service. Matthew Vaughn, 2014)

- Mátrix (The Matrix. Lana Wachowski és Lilly Wachowski, 1999)

- Mission Impossible 2. (Brian De Palma, 2000)

- No Blade of Grass (Cornel Wilde, 1970)

- Operation Delta Force (Sam Firstenberg, 1997)

- Repüló erôd (Deadly Outbreak. Rick Avery, 1995)

- Szabadulás (The Passage. TV-sorozat. Liz Heldens, 2019)

- The Walking Dead (TV-sorozat. Frank Darabont, Angela Kang, 2010-)

- Utopia (TV-sorozat. Dennis Kelly, 2013-14)

- Virus (Outbreak. Wolfgang Petersen, 1995)

- V-Wars - Vérháború (TV-sorozat. Brad Turner, Ted Adams, 2019-)

- $Z$ világháború (World War Z. Marc Forster, 2013) 
(C) Apertúra, 2020. Ỗsz | www.apertura.hu

webcím: https://www.apertura.hu/2020/osz/hodosy-mi-vagyunk-a-virus-a-fertozes-mint-

okopolitikai-metafora-a-jarvanyfilmekben-a-szornyfilmekben-es-a-kulturalis-kepzeletben/

https://doi.org/10.31176/apertura.2020.16.1.8

(Q) opertúro 